\title{
Odkrycie złóż oraz początki górnictwa węgla brunatnego w Zielonej Górze
}

\section{Discovery of deposits and beginnings of lignite mining in Zielona Góra}

The work describes the discovery of lignite deposits by C.A. Pohlez in 1838 near Zielona Góra that initiated extraction of this mineral coal by several mines.

Exploitation of lignite in Zielona Góra and its neighbourhood was taking place in the years 1841-1948. The article describes only the first years of mining and creation of the Gewerkschaft "Consolidierte Grünberger Gruben", which embraced almost all mines in the vicinity.

Extraction of lignite was conducted in the Wilkanowo and Stone villages near Zielona Góra, and also in the western part of the city. The text describes areas where particular mines belonging to the Gewrkschaft worked and presents well-known locations of the oldest mineshafts. It also presents available historical maps containing data on mining in the area of Zielona Góra and, on the basis of few preserved source materials and the 19th-century geological and mining literature, certain data concerning employment and the amount of extraction. The article introduces us also to the economic situation of the 19th-century Gewerkschaft.

Keywords: Zielona Góra, "Consolidierte Grünberger Gruben”, lignite mining, lignite mine, history of mining

Słowa kluczowe: Zielona Góra, „Consolidierte Grünberger Gruben”, górnictwo węgla brunatnego, kopalnia węgla brunatnego, historia górnictwa

\section{Wstęp}

Eksploatacja złóż węgla brunatnego na Ziemi Lubuskiej rozpoczęła się w 1820 r. w okolicach Sulęcina (kopalnia „Caroline\&Herrmann” w Gliśnie') i trwa do dziś (kopalnia odkrywkowa „Sieniawa” w Sieniawie Lubuskiej, powiat świebodziński). Węgiel brunatny, będąc 
tanim i lokalnym paliwem dla maszyn parowych, przyczynił się znacząco do rozwoju miejscowego przemysłu w XIX w., a następnie w XX w. do elektryfikacji tych ziem².

Zielona Góra (niem. Grünberg) już w latach trzydziestych XIX w. stała się miejscem ważnym dla górnictwa węgla brunatnego, dzięki odkryciu jego złóż przez Carla Pohlenza. Powstało tutaj jedno z najstarszych przedsiębiorstw zajmujących się jego wydobyciem - „Consolidierte Grünberger Gruben” (Zjednoczone Kopalnie Zielonogórskie)³. Według niektórych autorów są one najstarszą kopalnią węgla brunatnego na Dolnym Śląsku, do którego do 1945 r. zaliczano Zieloną Górę. Taką informację podali w swych pracach m.in. Rosenberg-Lipinsky ${ }^{4}$ Stein ${ }^{5}$, Czajka $^{6}$, Żaba $^{7}$ czy Zimmermann ${ }^{8}$.

Niniejsza praca ma za zadanie przybliżyć historię odkrycia węgla brunatnego oraz pierwszych lat funkcjonowania zielonogórskich kopalń i oparta jest na nielicznych zachowanych materiałach źródłowych oraz XIX-wiecznej literaturze górniczej.

\section{Odkrycie węgla brunatnego w okolicy Zielonej Góry}

Najstarsze znane zapiski o kopalni węgla (nie używano wówczas jeszcze terminu „brunatny") w tej części Europy znajdują się w spisie lenn arcybiskupa Magdeburga z 1382 r. i dotyczą wsi Lieskau koło Halle (Salle) ${ }^{9}$.

W pełni udokumentowane odkrycie węgla brunatnego na Ziemi Lubuskiej (ówczesnej wschodniej Brandenburgii) miało miejsce w 1801 r. w okolicy Sulęcina ${ }^{10}$. Odkrycie to nie pociągnęło jednak za sobą eksploatacji, m.in. z powodu wojen napoleońskich.

Dopiero kilkadziesiąt lat później, głównie dzięki rozwojowi maszyn parowych, które wymagały dużych ilości opału, zwrócono uwagę na licznie występujące złoża węgla brunatnego. Najważniejszym źródłem energii było wówczas drewno oraz węgiel kamienny, sprowadzany drogą morską (a następnie Odrą) z Anglii' ${ }^{11}$. Pierwszy cechował się jednak dość niską kalorycznością, a drugi wysoką ceną. Dzięki temu lokalny węgiel brunatny mógł się stać w krótkim czasie podstawowym surowcem napędzającym maszyny parowe w dolnośląskich fabrykach ${ }^{12}$. Dodatkowo, po wynalezieniu sposobu produkcji brykietów z miału

2 W. Krajniak, Elektryfikacja Ziemi Lubuskiej 1894-1955, „Studia Zachodnie” 2015, nr 17, s. 124.

3 A. Gontaszewska, A. Kraiński, "Consolidierte Grünberger Gruben" - zarys historii, [w:] Dzieje górnictwa - element europejskiego dziedzictwa kultury 3, red. P. Zagożdżon, M. Madziarz, Wrocław 2010, s. 110.

4 Rosenberg-Lipinsky, Die Verbreitung der Braunkohlen-formation im nördlichen Theile der Provinz Schlesien, „Jahrbuch der Königlich Preussischen Geologischen Landesamt und Bergakademie zu Berlin für das Jahr 1891" t. 12, 1893, s. 205.

5 E. Stein, Die Stadt Grünberg in Schlesien, Berlin 1928, s. 97.

6 W. Czajka, Der Schlesische Landrücken, Eine Landeskunde Nordschlesiens, Teil II, Breslau 1938, s. 304.

7 J. Żaba, Historia eksploatacji surowców mineralnych, [w:] Surowce mineralne Ziemi Lubuskiej, red. S. Kozłowski, Warszawa 1978, s. 15-18; idem, Historia eksploatacji węgla brunatnego na terenie Środkowego Nadodrza, „Prace Naukowe Uniwersytetu Śląskiego” 1977, nr 169, Seria Geologia, nr 1, s. 118.

8 A.H. Zimmermann, Ostpreussens Bernstein und Lausitzer Braunkohle, „Sächsisches Archivblatt” 2005, nr 2, s. 13.

9 G. Hertel, Die ältesten Lehnbücher der Magdeburgischen Erzbischöfe, Halle 1883, s. 197.

10 H. Cramer, Beiträge zur Geschichte des Bergbaues in der Provinz Brandenburg, Heft 1, Kreis Sternberg, Halle 1872, s. 2; A. Gontaszewska-Piekarz, „Caroline \& Herrmann” - pierwsza kopalnia węgla brunatnego na tle górnictwa Ziemi Lubuskiej, „Studia Zachodnie” 2018, nr 19 (w druku).

11 Węgiel dolno- oraz górnośląski nie był obecny na zielonogórskim rynku, zapewne w skutek braku połączeń kolejowych i wodnych. Por. M. Hempe, Kette und Schuss: die Tuchmacherei in Guben, Köln 2006, s. 86.

12 R. Staszewski, R. Wypiór, Rozwój górnictwa na Ziemiach Zachodnich Polski, [w:] Z geologii Ziem Zachodnich, t. 1. Wrocław 1966, s. 12. 
węgla brunatnego, znalazł on zastosowanie również w domach prywatnych jako materiał opałowy.

Odkrywcą złóż zielonogórskich był kupiec Carl Adolph Pohlenz (Rys. 1.). Pohlenz związany był zawodowo przez 35 lat z hutą żelaza (a następnie kuźnią) w Pliszce koło Krosna Odrzańskiego (niem. Pleiskehammer), po czym w 1837 r. przeprowadził się do Zielonej Góry i zajął się handlem artykułami żelaznymi ${ }^{13}$. Interesował się naukami przyrodniczymi, a w szczególności mineralogią i paleontologią. W komunikacie, jaki opublikował kilka lat po odkryciu węgla brunatnego opisuje wiele ciekawych znalezisk z okolic Zielonej Góry, m.in. sferosyderyty, skamieniałe drewno oraz liczne skamieniałości. Opisuje także nieczynną już kopalnię żwiru w Wilkanowie (niem. Wittgenau), gdzie w 1827 r. odkryto szkielet nieznanego zwierzęcia, a on sam dziesięć lat później trafił na jego szczątki ${ }^{14}$. Pohlenz na pod-

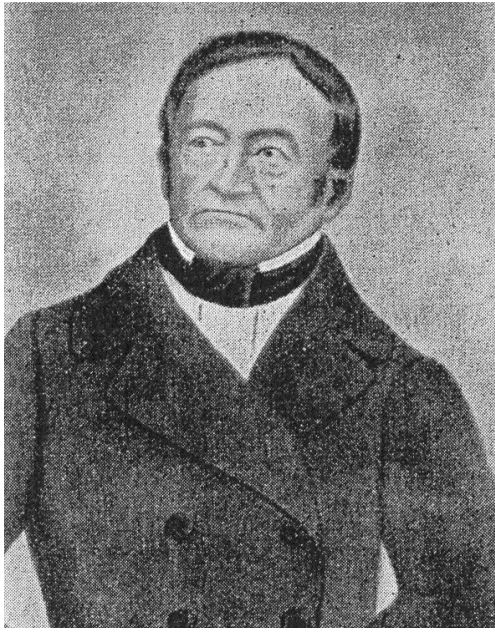

Rys. 1. Carl Adolph Pohlenz - odkrywca węgla brunatnego w okolicy Zielonej Góry oraz jeden z założycieli gwarectwa "Consolidierte Grünberger Gruben" (Peugler, 1940, s. 17). stawie obserwacji ukształtowania terenu oraz fragmentów skał znajdowanych w czasie swoich wędrówek w okolicach podzielonogórskich wsi doszedł do wniosku, że powinny tu występować złoża węgla brunatnego ${ }^{15}$. Surowca tego poszukiwano zwykle w okolicy wyrobisk (tzw. glinianek) licznych wówczas cegielni, gdyż węgiel brunatny znajdował się dość często poniżej wydobywanych tam iłów. Tak też było w przypadku kolonii Heinrichau (obecnie północno-zachodnia część wsi Wilkanowo), gdzie już na początku XIX w. funkcjonowały co najmniej 3 cegielnie zlokalizowane na południe od obecnej drogi Wilkanowo - Słone (niem. Schloin) ${ }^{16}$.

Pohlenz wytypował do poszukiwań teren należący do Friedricha Frenzla - sołtysa wsi Wilkanowo oraz właściciela wspomnianej kopalni żwiru. 21 września 1838 r. zwrócił się do Królewskiego Wyższego Urzędu Górniczego w Brzegu ${ }^{17}$ o pozwolenie na wykonanie w tej okolicy szurfów (wkopów) badawczych. Pozwolenie to uzyskał 27 listopada 1838 r. i następnie zatrudnił górnika Simona Merkla do wykonania poszukiwawczych szurfów. W jednym z nich, na głębokości 3 łatrów i 10 cali'18 (około 4,5 m) odkryto węgiel brunatny. Pohlenz nie był jednak zadowolony z pracy Merkla i odesłał go do domu.

Pozyskane w czasie poszukiwań próbki węgla zostały wysłane do Królewskiego Wyższego Urzędu Górniczego w Brzegu oraz do Królewskiej Komisji Górniczej z prośbą o ocenę oraz przysłanie do pomocy kompetentnego górnika. Urzędy przychyliły się do prośby

C.A. Pohlenz Kurze Nachricht, die Entdeckung der Braunkohlenlager in der Umgegend von Grünberg betreffend, „Abhandlungen der Naturforschenden Gesellschaft zu Görlitz” t. 5, 1848, nr 1, s. 72.

14 Ibid., s. 74. Opis tego znaleziska nie jest znany z innych źródeł.

15 Weimann, Ueber den Braunkohlenbau bei Grünberg, [w:] Uebersicht der Arbeiten und Veränderungen der schlesischen Gesellschaft für vaterländische Kultur im Jahre 1841, Breslau 1842, s. 72.

16 Mapa G.D. Reymann's topographische Special-Karte von Central Europa 1:200 000, Blatt 112 Glogau, 1831.

17 Siedziba Wyższego Urzędu Górniczego w latach 1819-1850 mieściła się w Brzegu, a nie we Wrocławiu.

18 tatr (niem. Lachter) $=2,09 \mathrm{~m}$, cal (niem. Lachterzoll) $=2,615 \mathrm{~cm}$. 
i 17 lipca 1839 r. Pohlenz podpisał umowę o pracę ze sztygarem Carlem Meyerem ${ }^{19}$. Dalsze poszukiwania węgla przeniosły się na południe od kolonii Heinrichau, gdzie w miejscu oznaczonym jako „Alte Vollerde Grube” trafiono pod iłami na miąższy pokład węgla brunatnego. Miejsce to zostało oznaczone jako tzw. „Fundpunkte” pola górniczego. Na tej podstawie Pohlenz złożył 30 lipca 1839 r. zgłoszenie pola górniczego (niem. Muthung) ${ }^{20}$ do Urzędu Górniczego w Wałbrzychu, któremu wówczas podlegała Zielona Góra²1. Kolejne poszukiwania, tym razem na terenie należącym do parafii katolickiej w Słonem (niem. Schloin), wykazały występowanie pokładu węgla o miąższości 16 stóp (około $5 \mathrm{~m}$ ). Zachowała się mapa odwiertów oraz wkopów z 1840 r., wykonanych na południe oraz na północ od drogi Słone - Wilkanowo ${ }^{22}$. Większość z wykonanych szurfów i odwiertów wykazała występowanie węgla brunatnego na głębokości kilku-kilkunastu metrów poniżej powierzchni terenu ${ }^{23}$ (Rys. 2.).

Badania do tego momentu finansował Pohlenz z własnych środków, nie był jednak w stanie ich kontynuować. Podpisał zatem z kilkoma majętnymi mieszkańcami miasta (doktorem medycyny Schrayerem, senatorem Gremplerem, kupcem Manniglem oraz bankierem Schuhmannem) roczny kontrakt na dalsze poszukiwania. Wykonane wiercenia nie zakończyły się jednak sukcesem. Z finansową pomocą tym razem przyszedł najstarszy syn odkrywcy - Adolph Bernhard Pohlenz, księgowy w hucie żelaza należącej do ich krewnego, Carla von Querfurt z Schönweyda w Górach Kruszcowych, wykładając ze swych oszczędności 200 talarów ${ }^{24}$. W sierpniu 1840 r. w odwiercie wykonanym na północno-zachodnim krańcu Słonego (pole rolnika o nazwisku Nieschalk) natrafiono na pokład węgla brunatnego o miąższości 34 stóp (około 10,5 m). Pohlenz wspomina, że w tym czasie usłyszał także o innych miejscach, gdzie stwierdzono występowanie węgla brunatnego m.in. okolice młyna Peiskera w Ochli (niem. Ochelhermsdorf), oraz okolicy Stampmühle w Słonem (Rys. 3.). Stąd prawdopodobnie wzięła się błędna informacja, że to właśnie tam Pohlenz po raz pierwszy nawiercił węgiel ${ }^{25}$. Tymczasem zgłoszenia pola górniczego dla Ochli dokonał Treutler dopiero 21 grudnia 1840 r., a 12 lipca 1843 uzyskał nadanie dla tamtejszej kopalni „Glückauf"26.

19 C.A. Pohlenz, op. cit., s. 78.

20 Ubiegający się o pozwolenie na eksploatację musiał złożyć zgłoszenie (Mutung) w Wyższym Urzędzie Górniczym (Oberbergamt), podając miejsce znalezienia węgla (Fundpunkt) oraz proponowane rozmiary i nazwę pola górniczego. Urząd górniczy sprawdzał, czy na danym terenie wcześniej nie ustanowiono już nadania - decydowała kolejność zgłoszenia. Po spełnieniu warunków ubiegający się otrzymywał nadanie górnicze (Verleihung).

21 R. Banduch, Mapy górnicze ze zbiorów Wyższego Urzędu Górniczego we Wrocławiu w latach 1769-1945, „Prace Naukowe Instytutu Górnictwa Politechniki Wrocławskiej” 2006, nr 117, s. 5.

22 Situation und Profile über die Bohr und Schurfarbeit auf Wittgenauer und Schloiner Terrain, Kgl. Oberbergamt Breslau, 1840; Situation und Profil Riss von der Schurfarbeit zwischen den Doerfen Schloin und Wittgenau bei Grünberg (odrys), materiały nieskatalogowane z archiwum prof. E. Ciuka, Archiwum Państwowego Instytutu Geologicznego, Warszawa.

23 Jak wynika z zachowanych map górniczych, obszar na północ od wymienionej drogi wszedł w późniejszych latach w obręb pól górniczych „Elisabeth” oraz „Victoria”, a w kolejnych (ok. 1858-1860) w jego północnej części funkcjonował szyb „Victoria”, a następnie (po 1884 r.) szyby Kaiser Wilhelm I oraz Kaiser Wilhelm II.

24 C.A. Pohlenz, op. cit., s. 79.

25 Dotychczas podawano, że odkrycie węgla miało miejsce w okolicy młyna Peiskera (Peiskermühle) w północnej części podzielonogórskiej wsi - Ochli. Por.: Z. Bujkiewicz, Kopalnia węgla brunatnego w Zielonej Górze", "Studia Zielonogórskie" 1997, nr 3, s. 80; H. Peugler, Die alten fünf Bergwünsche. 100 Jahre Grünberger Braunkohlengruben, Grünberg 1940, s. 5; E. Stein, op. cit., s. 97.

26 Archiwum Państwowe w Zielonej Górze [AP ZG], zespół 89/45/0 Sąd Obwodowy w Zielonej Górze, sygn. 4158, Acta betr. das Hypotheken Wesen der Braunkohlen Zeche Glückauf zu Mittel Ochelhermsdorf, Vol. I. 


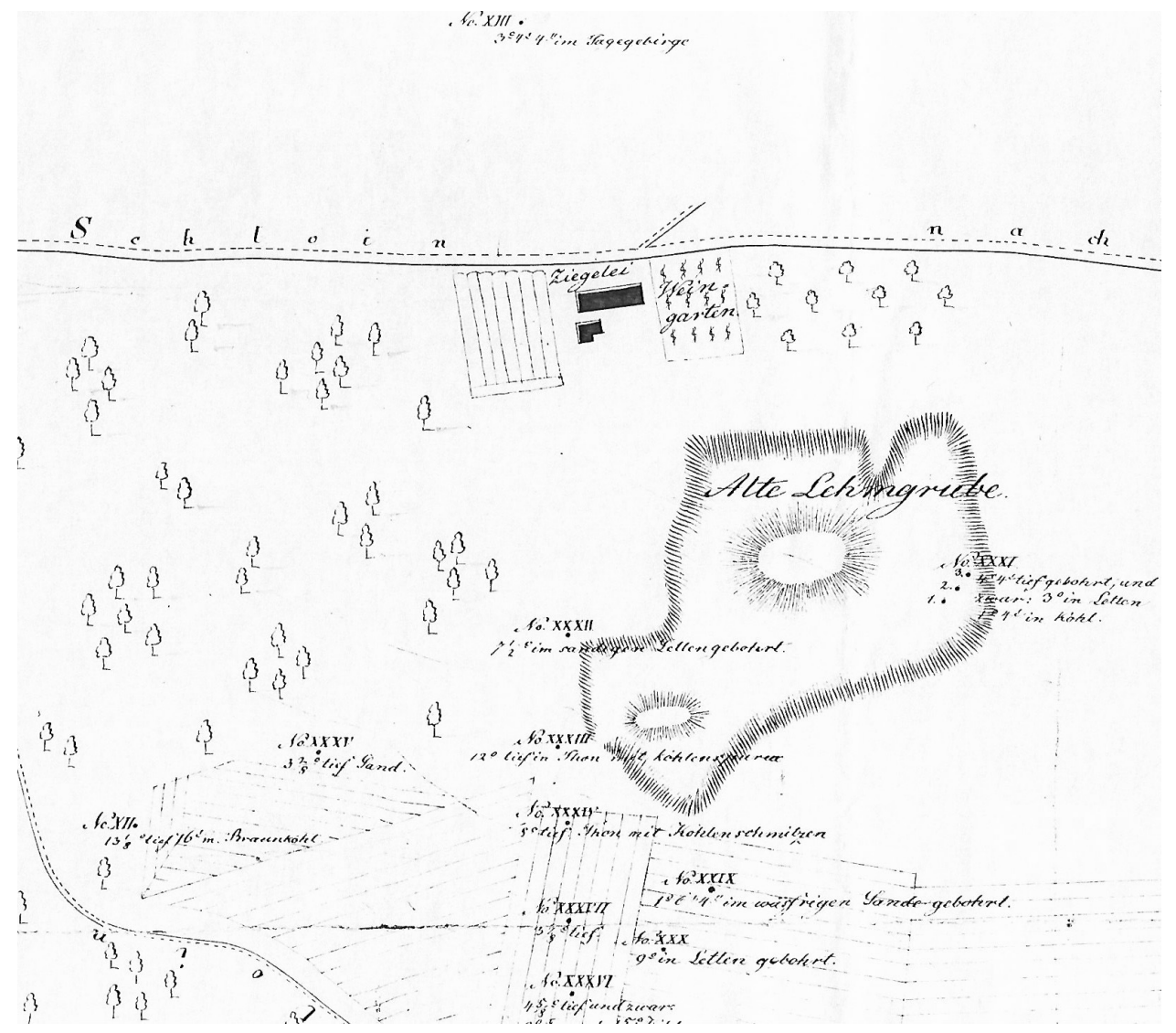

Rys. 2. Fragment mapy Situation und Profile über die Bohr und Schurfarbeit auf Wittgenauer und Schloiner Terrain, Kgl. Oberbergamt Breslau, 1840, oryginalna skala ok. 1:1450, zachodnie część kolonii Heinrichau (obecnie Wilkanowo), ze zbiorów prof. E. Ciuka (Archiwum Państwowego Instytutu Geologicznego we Warszawie nieskatalogowane). Objaśnienia: Ziegelei - cegielnia, Weingarten - winnica, Alte Lehmgrube - dawna kopalnia gliny (glinianka), No XXX - odwiert lub wkop (szurf) poszukiwawczy.

2 października 1840 r. Pohlenz spotkał się w Białym Kamieniu pod Wałbrzychem z tajnym radcą Carlem Georgiem Treutlerem i zawarł z nim wstępną umowę o finansowaniu dalszych poszukiwań ${ }^{27}$. Carl Treutler był znanym wałbrzyskim przedsiębiorcą oraz założycielem odlewni żeliwa, późniejszej huty „Karol”. Rodzina Treutlerów odegrała bardzo istotną rolę w uprzemysłowieniu Wałbrzycha, była także akcjonariuszem tamtejszych kopalń węgla kamiennego.

15 października 1840 r. Pohlenz i Treutler zgłosili do urzędu pole górnicze o nazwie „Friedrich Wilhelm”, obejmujące Wilkanowo oraz Słone. Datę tę można zatem uznać za początek kopalni o tej samej nazwie ${ }^{28}$. Nie wiadomo, kiedy uzyskali oni nadanie (niem. Verleihung) - pozwolenie na otwarcie kopalni i rozpoczęcie wydobycia. 24 listopada $1840 \mathrm{r}$. 


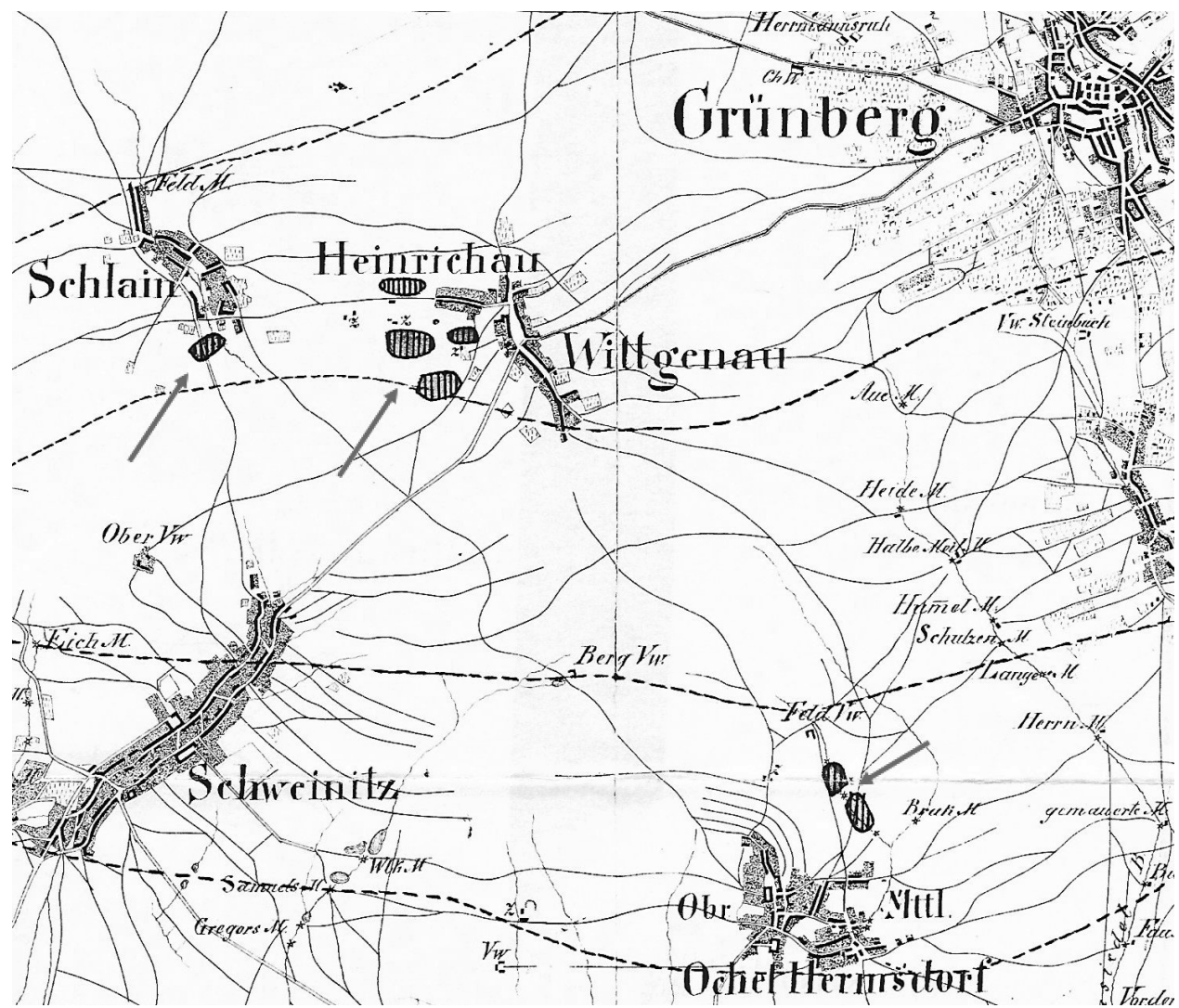

Rys. 3. Fragment mapy Karte von der Umgebung von Grünberg w skali 1:50 000, 1844. Zaznaczono rozpoznane złoża węgla brunatnego na północ od Ochli (Ochelhermsdorf) oraz w okolicy kolonii Heinrichau (Wilkanowo) i Słonego (Schlain). Ze zbiorów prof. E. Ciuka (Archiwum Państwowego Instytutu Geologicznego we Warszawie, nieskatalogowane).

Carl Pohlenz podpisał oficjalną umowę o współpracy i finansowaniu z Carlem Treutlerem, dotyczącą obszaru w promieniu sześciu mil29 (około $45 \mathrm{~km}$ ) od Zielonej Góry, tworząc oficjalnie kopalnię (zwaną także cechem) „Friedrich Wilhelm”30. W umowie zawarto zapis mówiący o przyznaniu Pohlenzowi udziałów w każdej kopalni, jaka w przyszłości powstanie na tym obszarze ${ }^{31}$.

Informacja o odkryciu zielonogórskich złóż rozprzestrzeniła się dość szybko. Już w 1843 r. opisywano je jako bardzo znaczące ${ }^{32}$.

29 Mila pruska (niem. Meile) $=7532 \mathrm{~m}$

30 H. Peugler, op. cit., s. 5; Weimann, op. cit., s. 73.

31 AP ZG, Acta betr. das Hypotheken Wesen der Braunkohlen Zeche Glückauf zu Mittel Ochelhermsdorf, Vol. I, zespół 89/45/0 Sąd Obwodowy w Zielonej Górze, sygn. 4158.

32 H. Göppert, Ueber das Braunkohlenlager bei Laasan, „Berg und Hüttenmännische Zeitung” 1843, s. 849. 
Kopalnia „Friedrich Wilhelm” uzyskała nadanie górnicze zapewne pod koniec 1840 r., po czym przystąpiono do robót górniczych - drążenia szybów i chodników transportowych. W międzyczasie inni zamożni mieszczanie zielonogórscy - kupcy oraz przemysłowcy - także zainteresowali się węglem brunatnym. Byli to przede wszystkim: Friedrich August Grempler, senator oraz właściciel wytwórni win i szampana Grempler\&Co. A.G., przemysłowiec Friedrich Gottlob Förster oraz kupiec Johann Samuel Mannigel. Zostali oni właścicielami wielu pól górniczych oraz nadań w okolic Zielonej Góry. Jednak zamiast otwierać samodzielne kopalnie, postanowili zjednoczyć się i utworzyć gwarectwo (niem. Gewerkschaft) ${ }^{33}$.

28 listopada 1843 r. $^{34}$ zawarto w Wałbrzychu (na podstawie śląskiego prawa górniczego z 5 czerwca 1769 r. $^{35}$ ) umowę utworzenia gwarectwa na 14 nadaniach i polach górniczych (Tab. 1.). Zachował się notarialny odpis tej umowy, sporządzony rok później we Wrocławiu $^{36}$. Umowę tę podpisali i udziałowcami (czyli gwarkami) gwarectwa stali się: Carl George Treutler z udziałami 533/6 kuksów, Johann Samuel Mannigel z udziałami 175/ kuksów, asesor Wyższego Sądu Krajowego z Berlina (urodzony w Zielonej Górze) Paul Leopold Schuhmann z udziałami 175/ kuksów oraz Friedrich August Grempler z udziałami 175/6 kuksów. Na podstawie wspomnianej już umowy z 24 listopada 1840 r. przyznającej Carlowi Adolphowi Pohlenzowi 15 kuksów każdej kopalni, jaka w przyszłości powstanie na obszarze 6 mil od Zielonej Góry, także i on stał się współwłaścicielem gwarectwa. Pohlenz zrzekł się jednak 6 kuksów na rzecz Mannigla, Gremplera oraz Schuhmanna, uzyskując w zamian zwolnienie od konieczności pokrywania ewentualnych strat gwarectwa (niem. Zubußen). Warto zaznaczyć, że w umowie nie pojawia się późniejsza nazwa gwarectwa - „Consolidirte Grünberger Gruben”. Do gwarectwa nie weszła działająca już wtedy kopalnia „Friedrich Wilhelm”.

W 1849 r. udziały Schuhmanna wykupił zielonogórski przemysłowiec Friedrich Gottlob Förster, a w 1856 r. po śmierci Johanna Mannigla udziałowcami stały się jego dzieci37. Od 1869 r. jako właściciel poszczególnych kopalń figuruje ogólnie gwarectwo. Zachowały się wpisy dotyczące własności w aktach hipotecznych ${ }^{38}$ między innymi dla kopalni „Glück Auf” z Ochli oraz „Consolidierte Carl” z Letnicy (Rys. 4).

Dla wszystkich kopalń, za wyjątkiem kopalni „Juliane” w Świdnicy, stosunek udziałów (kuksów) był taki sam (Rys. 4.). W przypadku kopalni „Juliane” połowa kuksów należała do miasta Zielona Góra ${ }^{39}$. Podział kuksów uległ zmianie w 1865 r., w skutek wprowadze-

33 Gwarectwo - spółka akcyjna zajmująca się wydobyciem surowców, akcje gwarectwa noszą nazwę kuksów. Kuksy mają charakter akcji objętych umownym ograniczeniem w ich zbyciu.

34 Gedenkblatt zum 50jährigen Bestehen der Consolidirten Grünberger Gruben, Grünberg i. Schl. 1890, s. 5. podaje datę 8 października 1841. Być może dotyczyło to umowy przedwstępnej. Umowa o utworzeniu gwarectwa nie mogła być jednak zawarta przed uzyskaniem poszczególnych nadań górniczych - por. tab.1.

35 Ibid., s.4.

36 AP ZG, Acta betr. das Hypotheken Wesen der Braunkohlen Zeche Glückauf zu Mittel Ochelhermsdorf, Vol.I, zespół 89/45/0 Sąd Obwodowy w Zielonej Górze, sygn. 4158.

37 Ibid.

38 Ibid.; AP ZG, Acta betr. das Hypotheken Wesen der Braunkohlen Zeche Consolidirte Carl zu Laetnitz, Gewerkschaft Emma-Braunkohlgrube, vol I, zespół 89/45/0 Sąd Obwodowy w Zielonej Górze, sygn. 4159.

39 Gedenkblatt zum 50jährigen Bestehen der Consolidirten Grünberger Gruben, Grünberg i. Schl., 1890, s. 6.; AP ZG, Grundakten Grunberg, Braukohlengrube Juliane, Bd II BI. 37, Gewerkschaft Emma-Braunkohlgrube, zespół 89/45/0 Sąd Obwodowy w Zielonej Górze, sygn. 4157. 


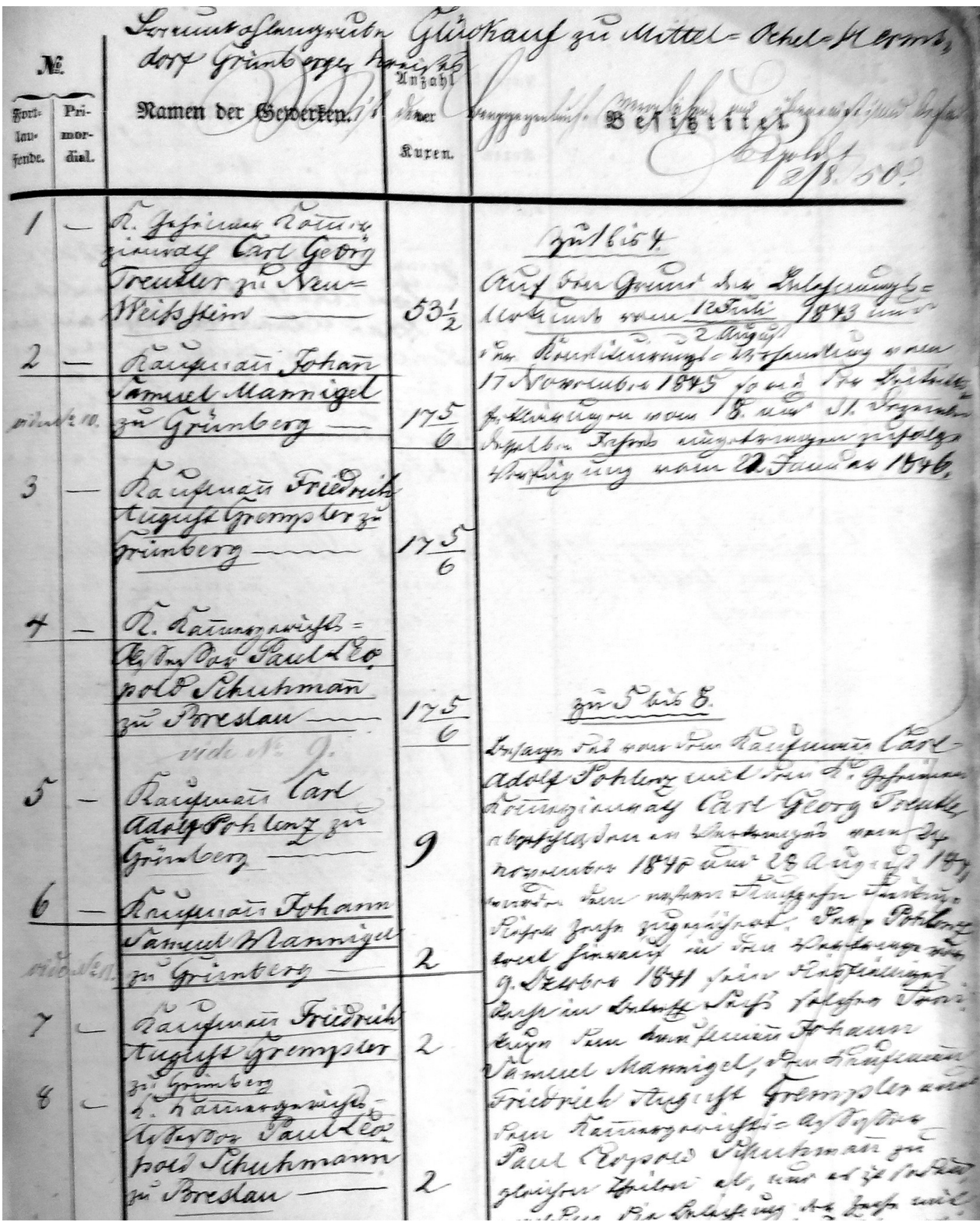

Rys. 4. Spis gwarków (udziałowców) kopalni "Glück Auf" z Ochli i jednocześnie całego gwarectwa "Consolidirte Grünberger Gruben". Acta betr. das Hypotheken Wesen der Braunkohlen Zeche Glückauf zu Mittel Ochelhermsdorf.

nia nowego prawa górniczego (Berggesetz z 24 czerwca 1865 r.) ${ }^{40}$. Prawo to wymagało podziału udziałów na 1000 kuksów (Rys. 5.), podczas gdy wcześniej było to 122 .

Trudno jest odtworzyć kolejne lata historii gwarectwa ze względu na prawie całkowity brak zachowanych dokumentów. Według wydawnictwa okolicznościowego z okazji 50-le- 
cia zielonogórskiego gwarectwa ${ }^{41}$ jego udziałowcy byli właścicielami łącznie 46 pól górniczych o łącznej powierzchni 94147 441,36 m², z czego 20 obszarów połączono pod nazwą "Consolidirte ${ }^{42}$ Grünberger Gruben”, a 2 („Carl Adolph" oraz "Carl Otto”) pod nazwą "Cons. Carl” [Consolidirte Carl]. Pozostałe pola górnicze pozostały pojedyncze i utworzono na nich między innymi kopalnie „Victoria”, „Kleine Agathe” (Rybno - Rys. 6.), "Kleine Christiane”, „Mathilde” (Szosa Kisielińska w Zielonej Górze), "Langersehnt Glück" (Nowy Kisielin), „Glück Auf"43 (Ochla), „Juliane”, „Zukunft” (Świdnica), „Förster” (Racula), „Kleiner Erich" oraz kopalnie o numerach 1 do $14^{44}$. Wydaje się jednak, że opis ten dotyczy późniejszych lat działalności gwarectwa, a nie jego początków. Z pewnością od pierwszych lat jego funkcjonowania dochodziło do połączeń (konsolidacji) poszczególnych pól górniczych oraz kopalń. Pola górnicze, zgła-

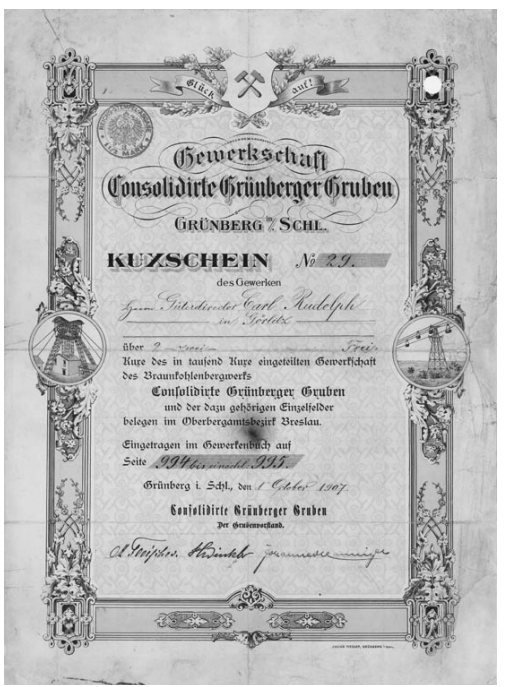

Rys. 5. Zaświadczenie nr 29 o posiadaniu dwóch kuksów gwarectwa "Consolidirte Grünberger Gruben", z kolekcji Marka Koneckiego. szane masowo w latach czterdziestych XIX w. (w oko-

Tab. 1. Zestawienie nadań górniczych (kopalń) oraz pól górniczych, jakie w r. 1843 weszły w skład gwarectwa

\begin{tabular}{|c|c|c|c|c|}
\hline Lp. & $\begin{array}{l}\text { Nadanie / pole } \\
\text { górnicze }\end{array}$ & Miejscowość & Właściciel & $\begin{array}{c}\text { Data nadania/ } \\
\text { zgłoszenia* }\end{array}$ \\
\hline 1. & "Friedrich August" & Jędrzychów (Heinersdorf) & F. A. Grempler & 18 marca 1843 \\
\hline 2. & "Elisabeth" & Słone (Schloin) & J. S. Mannigel & 18 marca 1843 \\
\hline 3. & "Johann Carl" & Drzonków (Drentkau) & J. S. Mannigel & 29 czerwca 1843 \\
\hline 4. & "Agnes" & Świdnica (Schweinitz) & J. S. Mannigel & 10 lipca 1843 \\
\hline 5. & „Beust" & Słone (Schloin) & C. G. Treutler & 11 czerwca 1843 \\
\hline 6. & "Erich" & Jędrzychów (Heinersdorf) & C. G. Treutler & 10 lipca 1843 \\
\hline 7. & „Florian” & Jędrzychów (Heinersdorf) & C. G. Treutler & 11 lipca 1843 \\
\hline 8. & "Reinhold" & Jędrzychów (Heinersdorf) & F. A. Grempler & 12 lipca 1843 \\
\hline 9. & "Glückauf" & Ochla (Ochelhermsdorf) & C. G. Treutler & 12 lipca 1843 \\
\hline 10. & "Langersehnt Glück" & $\begin{array}{l}\text { Stary Kisielin (Deutsch } \\
\text { Kessel) }\end{array}$ & J. S. Mannigel & 20 lipca 1843 \\
\hline 11. & "Christiane" & Zielona Góra (Grünberg) & C. G. Treutler & 24 lipca 1843 \\
\hline 12. & pole „Carl Otto" & Letnica (Laetnitz) & J. S. Mannigel & 8 września $1842^{*}$ \\
\hline 13. & pole „Leopold" & Świdnica (Schweinitz) & J. S. Mannigel & 9 września $1843^{*}$ \\
\hline 14. & $\begin{array}{l}\text { pole „Wilhelm } \\
\text { Heinrich" }\end{array}$ & Jędrzychów (Heinersdorf) & J. S. Mannigel & $\begin{array}{l}9 \text { października } \\
1842^{*}\end{array}$ \\
\hline
\end{tabular}

41 Ibid.

42 Termin ten, w zależności od ówcześnie obowiązujących reguł ortograficznych, był także zapisywany jako „Konsolidierte" lub „Consolidierte".

43 Zapisywane zarówno jako „Glück Auf”, jak i Glückauf”.

44 Gedenkblatt zum, s. 5. 


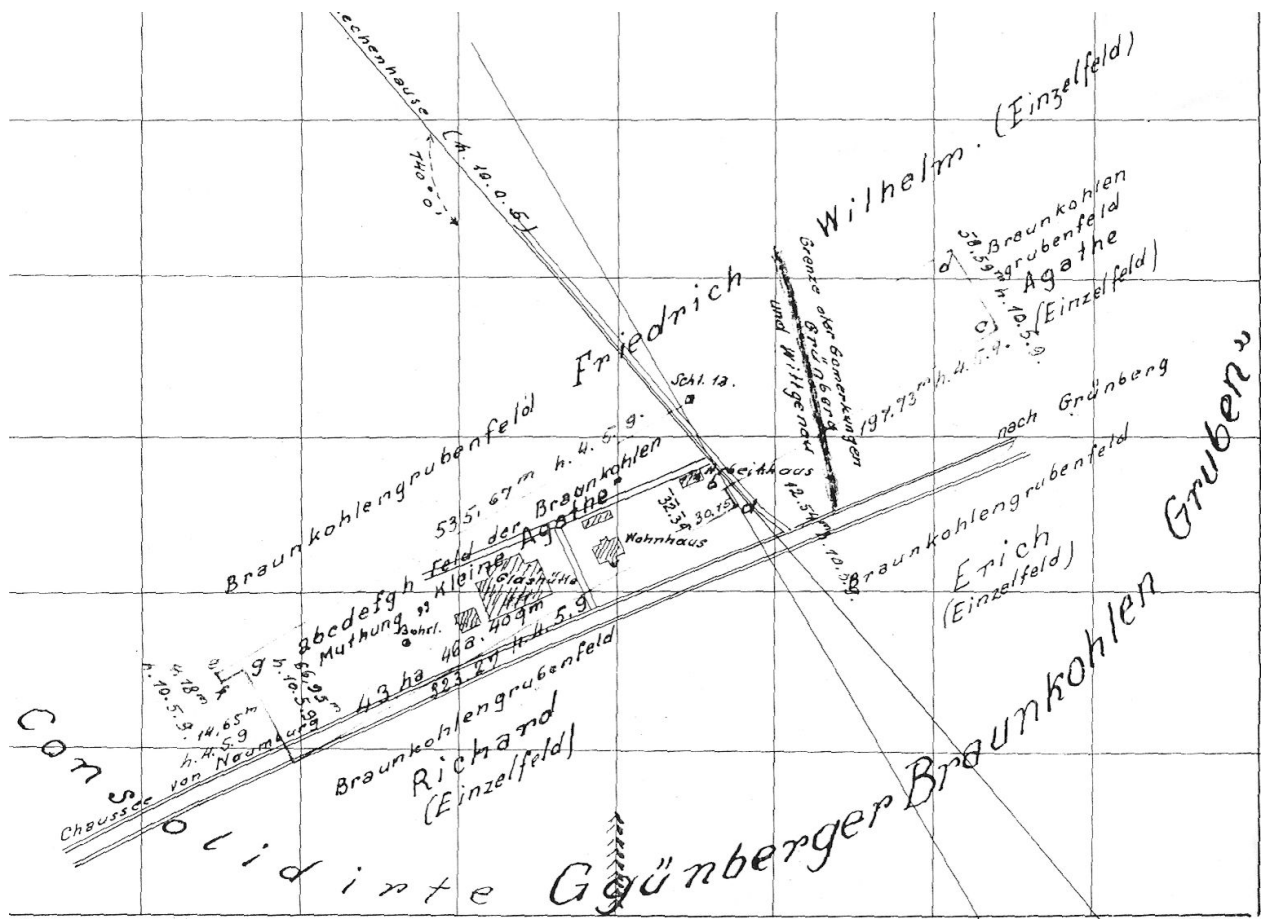

Rys. 6. Mapa pól górniczych gwarectwa „Consolidirte Grünberger Gruben” na terenie obecnego przysiółka Rybno. Widoczne budynki huty szkła (Glasshütte) - obecnie siedziba Nadleśnictwa Zielona Góra. Ze zbiorów prof. E. Ciuka (Archiwum Państwowego Instytutu Geologicznego we Warszawie, nieskatalogowane).

licy Zielonej Góry było ich co najmniej kilkadziesiąt) były sprzedawane i łączone w większe całości, a jedynie na części z nich powstały kopalnie (Rys. 7.). Już w r. 1844 wspomniana najstarsza zielonogórska kopalnia „Friedrich Wilhelm” połączyła się z kopalnią „Elisabeth" (kolonia Heinrichau, Wilkanowo), tworząc kopalnię „Konsolidierte Friedrich Wilhelm und Elisabeth Grube“, do której należały także pola górnicze „Alvensleben” oraz „Beust”45. Podobnie było z kopalnią "Konsolidierte Beust Grube", która powstała na połączonych polach górniczych „Caroline”, „Oswald”, „Franz”, „Friedrich August”, „Erich”, „Florian”, ,Reinhold” oraz „Wilhelm Heinrich", czy też kopalnią „Konsolidierte Agnes Grube” składającą się z pól „Agnes”, „Leopold” oraz „Eveline"46.

Odtworzenie dokładnych losów poszczególnych kopalń (funkcjonujących niekiedy zaledwie kilka lat) nie jest możliwe ze względu na brak materiałów źródłowych, które zachowały się fragmentarycznie. Dostępny jest między innymi dokument potwierdzający zjednoczenie kopalń „Christiane”, „Konsolidierte Agnes Grube” (Świdnica), „Konsolidierte Beust Grube” (Rybno-Jędrzychów), „Konsolidierte Friedrich Wilhelm und Elisabeth Grube” (Wilkanowo - Rybno),

45 J. Jaros, Słownik historyczny kopalń węgla na ziemiach polskich, Katowice 1984, s. 169.; C.A. Pohlenz, op. cit., s.80.

46 AP ZG, Acta betr. das Hypotheken Wesen der Braunkohlen Zeche Consolidirte Carl zu Laetnitz, Gewerkschaft Emma-Braunkohlgrube, vol I, zespół: 89/45 Sąd Obwodowy w Zielonej Górze, sygn. 4159; C.A. Pohlenz, op. cit., s. 80 . 


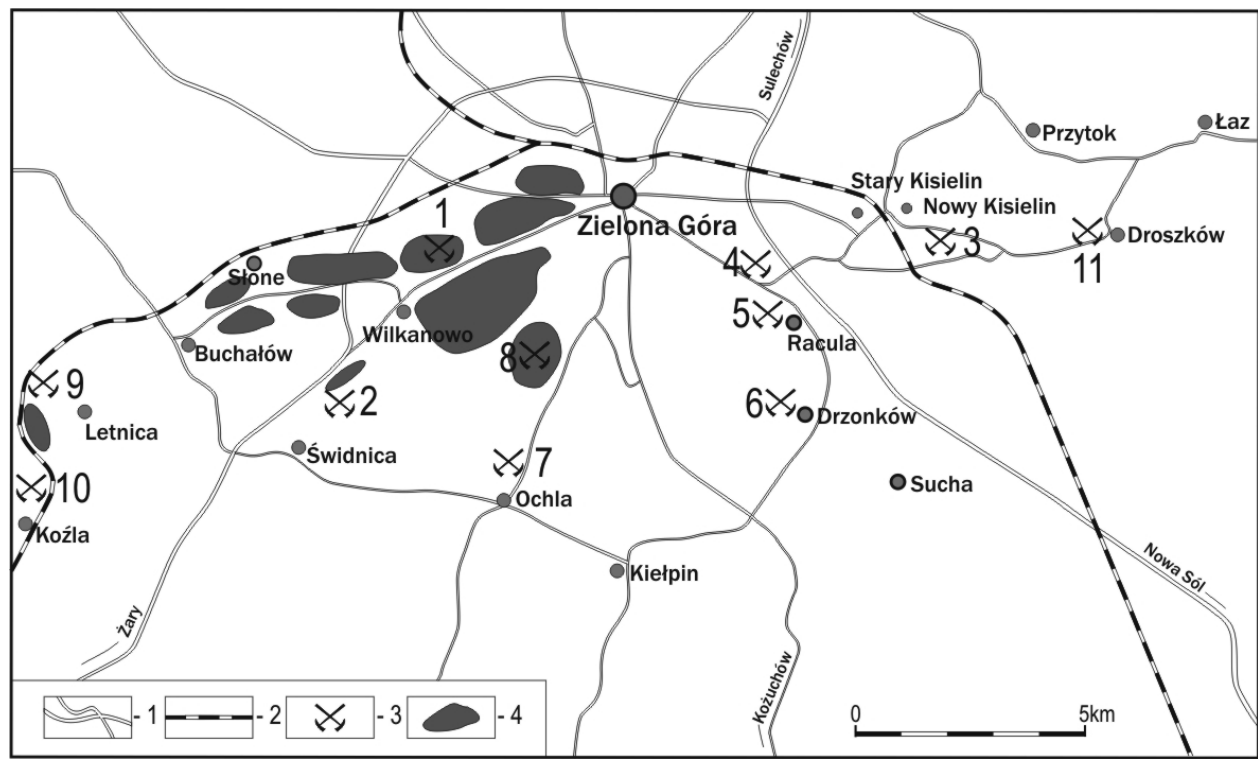

Rys. 7. Obszary eksploatacji węgla brunatnego w okolicy Zielonej Góry (Gontaszewska, 2015, zmienione i uzupełnione). Objaśnienia: 1 - główne drogi, 2 - linie kolejowe, 3 - mniejsze kopalnie, 4 - udokumentowane mapami obszary eksploatowane przez gwarectwo "Consolidierte Grünberger Gruben" do r. 1945. Oznaczenia kopalń należących do gwarectwa: 1 - Friedrich Wilhelm, 2-Zukunft, 3 - Langersehnt Glück, 4 - Mathilde, 5 - Förster, 6 - Johann Carl, 7 - Glück Auf, 8 - Beust, 9 - Consolidirte Carl; inne kopalnie: 10 - Cosel, 11 - Glückauf Ferdinand.

„Agathe” (Rybno), „Erdmenger”, „Richard”, „Beust Zubehör” łącznie z 19 innymi polami górniczymi jako „Bergwerk Konsolidierte Grünberger Gruben” z 6 marca 1861 r. ${ }^{47}$ oraz dokument (wraz z mapą) potwierdzający zjednoczenie 23 kopalń: „Konsolidierte Grünberger Gruben”, „Kleine Agathe”, „Kleiner Erich”, kopalnie o numerach 1 do 14, „Viktoria”, „Mathilde”, „Langersehnt Glück”, „Förster” oraz „Zukunft” pod nazwą „Braunkohlenbergwerk Konsolidierte Grünberger Gruben" z 8 lipca 1905 r. ${ }^{48}$. Wydaje się, że to właśnie zjednoczenie z r. 1861 „wprowadziło” nazwę „Konsolidierte Grünberger Gruben”, używaną do końca II wojny światowej. Nazwy tej używano już w kolejnych latach w różnych urzędowych wykazach ${ }^{49}$.

Gwarectwo posiadało także dwa pola górnicze w okolicy Żagania: „Amsel” oraz „Gottes Segen", o łącznej powierzchni 4,378 km², lecz brak jest informacji o rozpoczęciu eksploata$\mathrm{cji}^{50}$. Najprawdopodobniej pola te zostały w późniejszych latach sprzedane, gdyż zachował się dokument mówiący o rozwiązaniu w 1941 r. gwarectw o tych właśnie nazwach ${ }^{51}$.

Sächsisches Staatsarchiv [SSarch], Braunkohlenbergwerk Konsolidierte Grünberger Gruben bei Grünberg - Berechtigung, zespół: 40048 (preußisches) Bergamt (Bergrevier) Görlitz, Nr. 1-468; Jahrbuch des Schlesischen Vereins für Berg- und Hüttenwesen, Breslau 1861, s. 103.

48 AP ZG, Acta betr. das Hypotheken Wesen der Braunkohlen Zeche Consolidirte Carl zu Laetnitz, Gewerkschaft Emma-Braunkohlgrube, vol. I, zespół: 89/45 Sąd Obwodowy w Zielonej Górze, sygn. 4159.

49 Dane statystyczne kopalń zawarte w Zeitschrift für das Berg-, Hütten u. Salinen -Wesen, Berlin, 1864

50 Gedenkblatt zum, s. 5.

51 SSarch, Repräsentanten und Grubenvorstände - Allgemein, Auflösung der Gewerkschaften Amsel, Gottessegen und Glückauf in Grünberg, zespół: 40048 (preußisches) Bergamt (Bergrevier) Görlitz, Nr. 1-698; Repräsentanten und Grubenvorstände - Allgemein, Auflösung der Gewerkschaften Amsel, Gottessegen und Glückauf in Grünberg. 
Zdarzały się także sprzedaże funkcjonujących kopalń. W 1905 r. kopalnia „Consolidirte Carl" z Letnicy została sprzedana (najprawdopodobniej razem z polami górniczymi „Amsel" i „Gottes Segen” oraz niedziałającą już kopalnią „Glückauf” z Ochli) gwarectwu „Reichenau” z Bogaczowa52.

\section{Początki eksploatacji węgla brunatnego}

Wydobycie węgla brunatnego w okolicy Zielonej Góry rozpoczęła kopalnia „Friedrich Wilhelm" należąca do Treutlera oraz Pohlenza. W 1840 r. zatrudniono Juliusa Schwidtala jako sztygara dla kopalń „Friedrich Wilhelm”, „Juliane”, „Oswald” „Franz” oraz „Cornaline" (tylko dwie pierwsze uruchomiły wydobycie) ${ }^{53}$. Schwidtal został w późniejszych latach dyrektorem kopalń i pełnił tę funkcję do $1872 r^{54}$

Pierwszym szybem w okolicy Zielonej Góry był szyb „Carl George”, uruchomiony 15 października 1841 r. $^{55}$ Jego dokładna lokalizacja nie jest znana, nie odnaleziono bowiem dotychczas żadnej mapy, na której byłby zaznaczony. Można jednak przypuszczać, że znajdował się on w północno-wschodniej części wsi Słone. W szybie "Carl George" nie napotkano jednak odpowiednich ilości węgla i konieczne było wykonanie kolejnego szybu ${ }^{56}$.

Szyb „Emilie” znajdował się 1/2 mili (około 3,7 km) od szybu „Carl George” i około 1/8 mili (około $350 \mathrm{~m}$ ) na północ od Naumburger Strasse (obecnie ulica Łużycka), przy drodze prowadzącej do wsi Słone (dzisiejszy przysiółek Rybno) - Rys. 8. Od listopada 1841 r. wydobycie węgla było nieprzerwane, a zasoby węgla szacowano w nim na 5060 lat (w rzeczywistości szyb funkcjonował znacznie krócej). Głębokość szybu wynosiła 35 stóp (około $10 \mathrm{~m}$ ), a miąższość pokładu węgla około 10-14 stóp (około 3-3,5 m) ${ }^{57}$. Lokalizacja szybu „Emilie” jest pewna, gdyż jest on zaznaczony na wielu późniejszych mapach jako najstarszy szyb gwarectwa. W większości materiałów źródłowych, nawet pochodzących z lat 40 . XIX w. jest on datowany na 1840 r. i opisywany jako pierwszy szyb zielonogórskich kopalń ${ }^{58}$. Zachował się także odrys mapy kopalni „Friedrich Wilhelm” z widocznym szybem „Emilie"59.

W 1843 r. wydobycie z szybu „Emilie” wynosiło około 50-70 ton pruskich ${ }^{60}$ na dobę przy zatrudnieniu 9 górników. 30 kolejnych zatrudnionych było przy wierceniach. Mniej więcej $1 / 3$ węgla wydobywana była w postaci pylastej (niem. Staubkohle), a pozostała część jako tzw. „kostka” (niem. Würfelkohle). Znany jest bardzo schematyczny przekrój przez szyb kopalni „Friedrich Wilhelm” (Rys. 9.).

W 1847 r. czynne były trzy szyby kopalni „Konsolidierte Friedrich Wilhelm und Elisa-

52 AP ZG, Acta betr. das Hypotheken Wesen der Braunkohlen Zeche Consolidirte Carl.

53 „Der Berkwerksfreund - ein Zeitblatt für Berg- und Hüttenleute” t. 6, 1843, s. 76.

54 Gedenkblatt zum, s. 7.

55 Weimann, op. cit., s. 73.

56 „Grünberger Wochenblatt" 1843, nr 5, s.1.; Weimann, op. cit., s. 73.

57 Weimann, op. cit., s. 73.

58 J.G. Knie, Alphabetisch-statistisch-topographisch Uebersicht der Dörfer, Flecken, Stäste und andern Orte der Königl. Preuß. Provinz Schlesien, Breslau 1845, s. 751.

59 Odrys mapy Vermessungs Riss von der Friedrich Wilhelm Grube bei Schloin, materiały nieskatalogowane z archiwum prof. E. Ciuka, Archiwum Państwowego Instytutu Geologicznego, Warszawa.

60 Tona pruska była miarą objętości, 1 tona pruska $=4$ buszle $=$ ok. 220 litrów. 


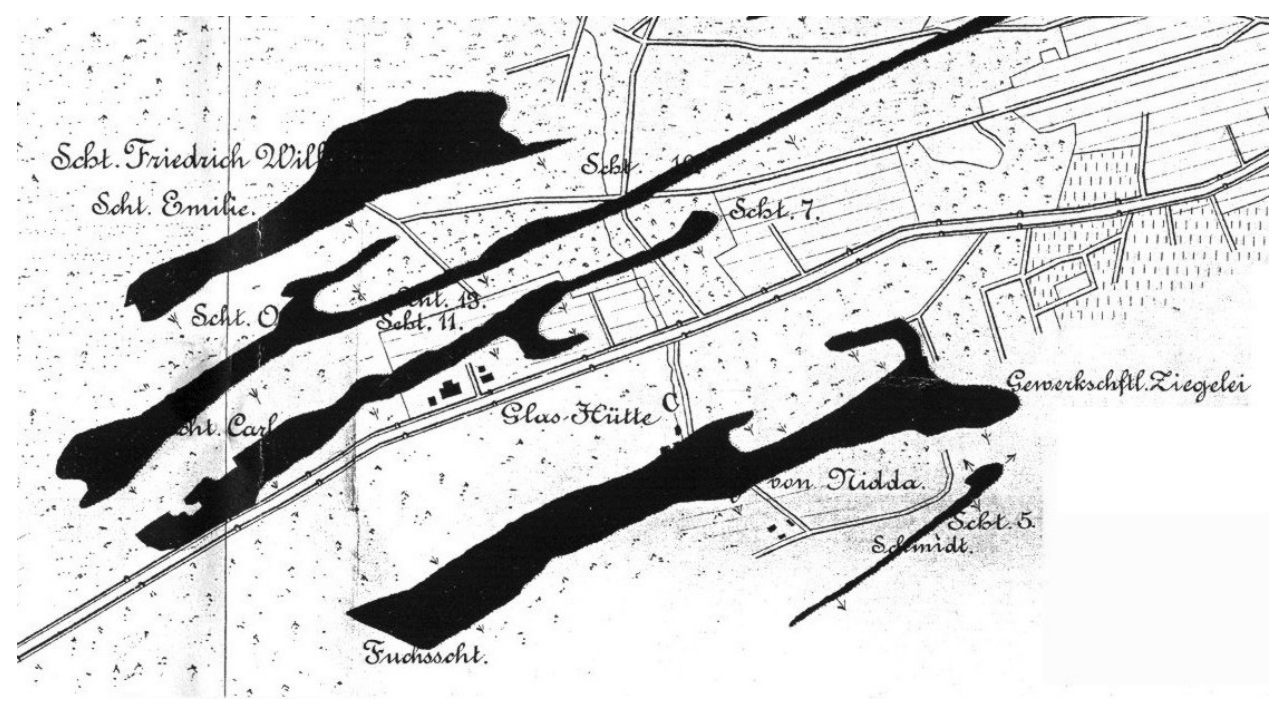

Rys. 8. Okolice obecnego przysiółka Rybno, południowy zachód od Zielonej Góry. Kolorem czarnym zaznaczono obszary eksploatacji węgla brunatnego. Objaśnienia: Scht - szyb, Gewerkschftl. Ziegelei - cegielnia gwarectwa, Glas Hütte - huta szkła, obecnie budynek Nadleśnictwa Zielona Góra (Gedenkblatt, 1890, wkładka).

\section{Fig $N$}

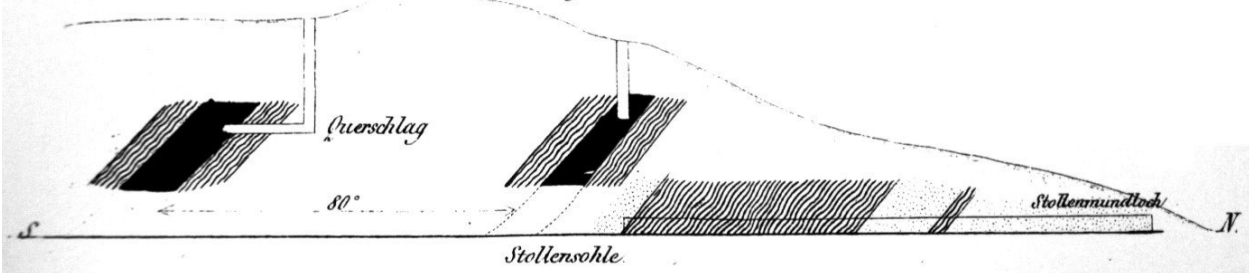

Rys. 9. Schematyczny przekrój przez pokład węgla brunatnego eksploatowany w kopalni Friedrich Wilhelm (Plettner, 1852).

beth Grube”: „Emilie”, „Jakob” oraz „Carl”61. Szyb „Carl” położony był na południowy zachód od szybu „Emilie”, blisko ówczesnej Naumburger Strasse. Zaznaczono go na kilku mapach górniczych. Warto zaznaczyć, że w 1901 r. powstał kolejny szyb o tej nazwie (pisany z reguły jako „Karl”), na południe od Naumburger Strasse. Szyb „Jakob” nie jest odnotowany na żadnej zachowanej mapie górniczej, brak też jakichkolwiek informacji na jego temat. Łączne wydobycie w 1847 r. wyniosło około 30 tys. ton pruskich (około 8600 ton) przy zatrudnieniu 40-50 górników, co w pełni zaspokajało popyt na węgiel w Zielonej Górze i okolicach ${ }^{62}$.

W pracy E. Plettnera z 1852 r. ukazała się informacja, że kopalnia „Friedrich Wilhelm” jest już nieczynna, a jej szyby zostały zlikwidowane (zasypane), gdy eksploatacja doszła do zwierciadła wód podziemnych ${ }^{63}$. Wydobycie miało natomiast miejsce w kopalni „Beust”

63 E. Plettner, Die Braunkohle In der Mark Brandenburg. Ihre Verbreitung und Lagerung, Berlin 1852, s. 46. 


\section{Braunfoblen}

werben von ieft ab nidbt mebr auf ber Friebrids= WBithelm:(S3rube bei Wittgenau, fondern auf bem Feinbolb: Schachte ner 23 eupt: Srube ver: Eauft. Die Serkaufs = פreife find die befannten: bie sonne (à 4 preußs. Stbeffel) Studfloblen 8 Sgr., $\mathbb{B}$ urfeltohlen 5 Sgr., Staubfoblen 1 Sgr. Der Reinbold = Sd)adht liegt füblich) ber nad) SBittgenau fúbrenben neu angelegten (5baulfee, gleids binter ben zum Rindenrevier geborigen $\mathbb{W}$ ein: bergen.

Şrůnberg, Den 6. 2uguit 1849.

\section{J. Schwidtal.}

Rys. 10. Ogłoszenie z „Grünberger Wochenblatt”, $\mathrm{nr} 64 \mathrm{z} \mathrm{r}$. 1849 , s. 6. (dokładniej „Konsolidierte Beust") ${ }^{64}$, znajdującej się „bliżej miasta" (Rys. 10.). Kopalnia ta (należąca do gwarectwa) znajdowała się na terenie przylegającym do ówczesnej cegielni, a wydobycie odbywało się w szybie "Reinhold" w latach 1849-1862 ${ }^{65}$. Zbliżone informacje podał C.F. Zincken w pracy z $1867 r^{66}$, prawdopodobnie opierając się na danych Plettnera.

Według Stownika historycznego kopalń węgla na ziemiach pol-

skich kopalnia „Beust” znajdowała się w obrębie wsi Jędrzychów (Heinersdorf) i działała w latach 1849-1861 wydobywając około 19 tys. ton pruskich ${ }^{67}$ rocznie (około 5400 ton), a jej właścicielem był Treutler $^{68}$. Z zachowanych dokumentów wynika jednak niezbicie, że kopalnia „Konsolidierte Beust” należała do gwarectwa, którego Treutler był najważniejszym udziałowcem ${ }^{69}$.

W latach 1852-1853 największe wydobycie (odpowiednio 50905 oraz 94920 ton pruskich) miała kopalnia „Richard” w Wilkanowie, której pole górnicze położone było bezpośrednio na południe od pola kopalni „Friedrich Wilhelm”, także należąca do gwarectwa ${ }^{70}$.

Spisy urzędowe zaświadczają o funkcjonowaniu w 1854 r. w okolicy Zielonej Góry trzech kopalń: „Consolidirte Beust” (Jędrzychów-Rybno), „Richard” (Wilkanowo) oraz „Glückauf Friedrich” w Zaborze ${ }^{71}$. W latach 1856-1857 wymieniona jest już tylko kopalnia „Beust"72. Kopalnia „Konsolidierte Friedrich Wilhelm und Elisabeth Grube“ wznowiła działalność w następnych latach, oddając do eksploatacji w 1858 szyb r. „Victoria” (okolice obecnych ulic Ceramicznej oraz Malczewskiego w Zielonej Górze). Wydobycie prowadzono do głębokości występowania wód podziemnych. Od 1859 r. oprócz szybu "Victoria”

64 Nazwa kopalni pochodzi od nazwiska zmarłego w r. 1859 Ernsta Augusta Grafa von Beust, najwyższego urzędnika górniczego w Królestwie Pruskim (Oberberghauptmann). Por.: Die Protokolle des Preußischen Staatsministeriums 1817-1934/38. Band 4/2, Hildesheim 2003, s. 546.

65 Według danych zawartych na mapie górniczej Consolidierte Grünberger Grube arkusz B20 oraz ogłoszenie w „Grünberger Wochenblatt” nr 64 z r. 1849.

66 C.F. Zincken, Die Physiographie der Braunkohle, Leipzig 1867, s.770.

67 Autor Słownika nie określił o jakich tonach mowa, jednak materiały źródłowe, na których się opierał podają wydobycie w tonach pruskich.

68 J. Jaros, op. cit., s. 16.

69 SSarch, Braunkohlenbergwerk Konsolidierte Grünberger Gruben bei Grünberg - Berechtigung , 40048 (preußisches) Bergamt (Bergrevier) Görlitz, nr 1-468.

70 Der Bergwerkbetrieb in dem Preussischen Staate im Jahre 1852, „Zeitschrift für das Berg-Hütten u. SalinenWesen" 1854, s. 80.

71 „Amts-Blatt Königlichen Regierung Liegnitz” 1854, nr 53, s. 540; Der Bergwerkbetrieb in dem Preussischen Staate im Jahre 1854, „Zeitschrift für das Berg-, Hütten- und Salinenwesen im Preussischen Staate” 1856, s. 79.

72 Der Bergwerkbetrieb in dem Preussischen Staate im Jahre 1857, „Zeitschrift für das Berg-Hütten u. SalinenWesen" 1858 , s. 108 
funkcjonował jeszcze szyb "Krug von Nidda"73 kopalni „Cons. Beust” na południe od drogi Zielona Góra - Wilkanowo (Rys. 9). Łączne wydobycie obu tych kopalń należących do gwarectwa wyniosło w 1858 r. - 129625 ton pruskich, a w 1859 r. 117478 ton pruskich, czyli około 20 tys. ton. Zatrudnienie wyniosło w tych latach 105 osób ${ }^{74}$.

Eksploatacja szybu „Krug von Nidda” związana było z wieloma technicznymi problemami. W 1858 r., pod koniec jego drążenia (na głębokości okoto $31,5 \mathrm{~m}$ ), natrafiono na kurzawkę, która wdarła się na podszybie. Dopływ wody z piaskiem był tak duży, że standardowe (drewniane) obudowy szybu nie wytrzymywały jej naporu. Konieczne było zastosowanie obudowy żeliwnej, w której udało się dokończyć głębienie szybu i wykonać murowaną obu-

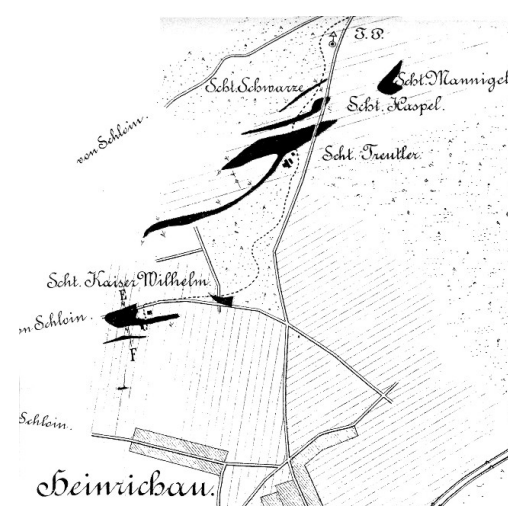

Rys. 11. Okolice kolonii Heinrichau (obecnie część wsi Wilkanowo). Kolorem czarnym zaznaczono obszary eksploatacji węgla brunatnego. Objaśnienia: Scht - szyb, F.P. - miejsce odkrycia złoża (Fundpunkt), Schloin - Słone (Gedenkblatt, 1890, wkładka). dowę podszybia. Po wykonaniu szybu przystąpiono do drążenia chodnika odwadniającego (niem. Sumpfstrecke), co również wymagało zastosowania żelaznej obudowy. Użyto eliptycznych łuków z żelaza walcowanego o grubości 1 3/4 oraz 3/8 cala, rozmieszczając je co około 1 metr, za którymi umieszczono grube deskowanie. Chodnik miał wysokość tylko 1⁄2 łatra (około $1 \mathrm{~m}$ ), gdyż musiał „zmieścić się" całkowicie w pokładzie węgla - przerwanie spągu lub stropu pokładu mogło skutkować kolejnym wdarciem się kurzawki do chodnika. Po zakończeniu tych trudnych prac oraz odpompowaniu ogromnych ilości wody, przystąpiono do eksploatacji złoża75.

Kolejny problem w kopalni „Cons. Beust” pojawił się w 1860 r., podczas drążenia przekopu (niem. Querschlag) pomiędzy dwoma pionowymi skrzydłami siodła (antykliny) pokładu węgla brunatnego. Projektowana długość przekopu wynosiła 14 łatry (około $29 \mathrm{~m}$ ), jednak po wykonaniu 10 łatrów do chodnika wdarła się kurzawka. Tu również musiano zastosować żeliwną obudowę ${ }^{76}$.

Sprawozdanie Urzędu Górniczego w Wałbrzychu ${ }^{77}$ (któremu wówczas podlegała Zielona Góra) za r. 1860 podaje dla kopalni „Konsolidierte Friedrich Wilhelm und Elisabeth Grube" wydobycie 85696 ton pruskich (około 24,5 tys. ton), a dla kopalni „Cons. Beust” 60602 tony pruskie (17,3 tys. ton $)^{78}$. Oprócz tych dwu kopalń należących do gwarectwa "Consolidirte Grunberger Gruben" w okolicy Zielonej Góry funkcjonowała ówcześnie jeszcze jedna kopalnia - „Glückauf Ferdinand” w Droszkowie (niem. Droschkau), należąca do księcia zu Schönaich-Carolath z Zaboru (niem. Saabor) ${ }^{79}$.

Nazwa szybu pochodzi od nazwiska Otto Ludwiga Krug von Nidda, ówczesnego dyrektora Wyższego Urzędu Górniczego we Wrocławiu. Por. H. Freydank, Krug von Nidda, Otto, [w:] Neue Deutsche Biographie 13, 1982, s. 116-117, oraz Gedenkblatt, s. 29.

74 Jahrbuch des Schlesischen Vereins für Berg- und Hüttenwesen, Breslau 1860, s. 11.

75 Ibid.

76 Ibid., s. 354.

77 Bergamt Waldenburg, podlegający Wyższemu Urzędowi Górniczemu we Wrocławiu (Oberbergamt Breslau), por. R. Banduch, op. cit., s. 5.

78 Jahrbuch des Schlesischen Vereins, 1861, s. 165.

79 Ibid.; Jaros, op. cit., s. 170. 
Tab. 2. Szyby wydobywcze Consolidierte Grünberger Gruben w latach 1840-1900, zestawienie autorki

\begin{tabular}{|c|c|c|c|}
\hline Szyb & Lokalizacja & Początek eksploatacji & Koniec eksploatacj \\
\hline Carl George & \multirow{8}{*}{$\begin{array}{l}\text { przysiółek Rybno } \\
\text { (Wilkanowo) }\end{array}$} & brak & \\
\hline Emilie & & 1841 & $\begin{array}{l}\text { po 1847, przed } \\
1852\end{array}$ \\
\hline Jakob & & po 1843, przed 1847 & przed 1852 \\
\hline 7 & & 1856 & b.d. \\
\hline $10,11,13$ & & po 1843 & b.d. \\
\hline Friedrich Wilhelm & & 1863 & b.d. \\
\hline Otto & & 1868 & 1882 \\
\hline Carl & & po 1843, przed 1847 & przed 1852 \\
\hline $\begin{array}{l}\text { 24,25, Helene, } \\
\text { Haide }\end{array}$ & $\begin{array}{l}\text { północny kraniec } \\
\text { Świdnicy }\end{array}$ & po 1847 & ok. 1890 \\
\hline $\begin{array}{l}\text { Kaiser Wilhelm I } \\
\text { Kaiser Wilhelm II }\end{array}$ & \multirow{5}{*}{ na północ od Wilkanowa } & $\begin{array}{l}1884 \\
\text { b.d. }\end{array}$ & $\begin{array}{l}\text { po } 1890 \\
\text { po } 1890\end{array}$ \\
\hline Schwarze & & b.d. & b.d. \\
\hline Treutler & & 1884 & po 1890 \\
\hline Hasper & & 1880 & b.d. \\
\hline Manningel & & 1884 & b.d. \\
\hline $8 / 9$ & \multirow{3}{*}{ Zielona Góra, os. Ceramiczne } & 1869 & 1870 \\
\hline 15 & & 1871 & $1910(?)$ \\
\hline Victoria & & 1858 & 1860 \\
\hline $14,18,19$ & \multirow{2}{*}{$\begin{array}{l}\text { Zielona Góra, al. Wojska } \\
\text { Polskiego, ul. Prosta }\end{array}$} & 1870 & 1871 \\
\hline 17 & & 1872 & 1875 (ро 1890?) \\
\hline 23 & Zielona Góra, ul. Leśna & 1878 & 1884 \\
\hline 2,5 & \multirow{6}{*}{$\begin{array}{l}\text { Zielona Góra, na południe } \\
\text { od ul. Łużyckiej oraz Rybna }\end{array}$} & 1850 & 1863 \\
\hline $\begin{array}{l}8,16 \\
\text { Krug von Nidda I } \\
\text { Krug von Nidda II }\end{array}$ & & $\begin{array}{l}1852 \\
1859 \\
1885\end{array}$ & $\begin{array}{l}1856 \\
1863 \\
1901\end{array}$ \\
\hline Fuchsschacht & & 1853 & 1861 \\
\hline Die Ruhe & & 1843 & przed 1890 \\
\hline Albert & & 1896 & 1901 \\
\hline Reinhold & & 1849 & 1863 \\
\hline
\end{tabular}

b.d.- brak danych 


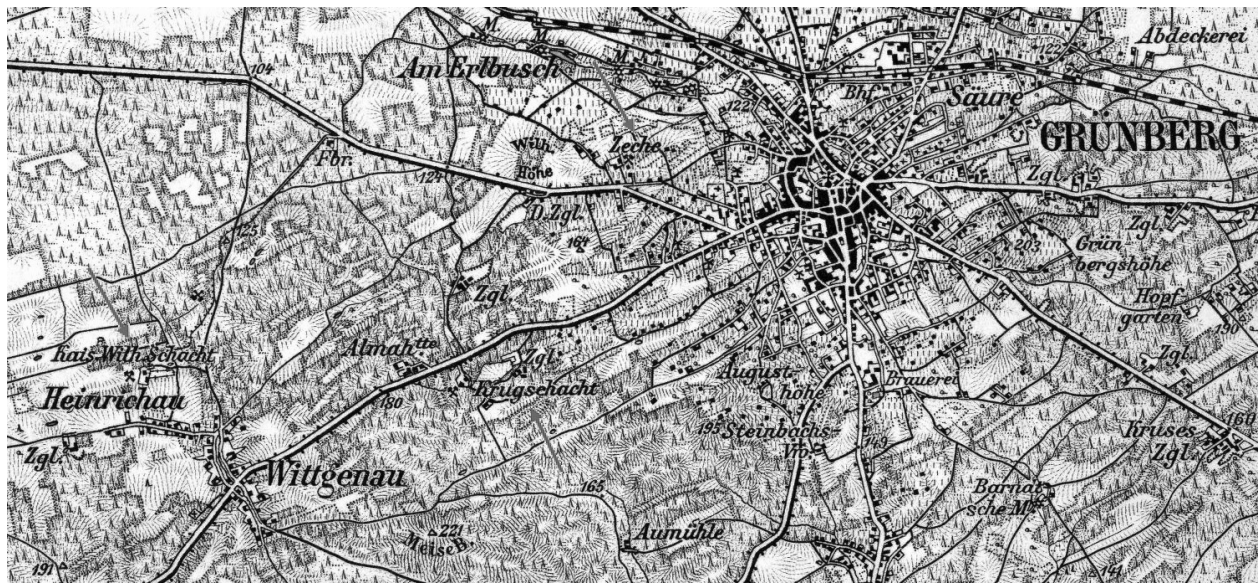

Rys. 12. Fragment mapy Deutsche Karte w skali 1:50 000, wydanie z $1893 \mathrm{r}$. Widoczne obiekty „Consolidierte Grünberger Gruben": Zeche (cechownia), Krugschacht (szyb Krug von Nidda), Kais.Wilh. Schacht (szyb Kaiser Wilhelm), Fbr - fabryka brykietów.

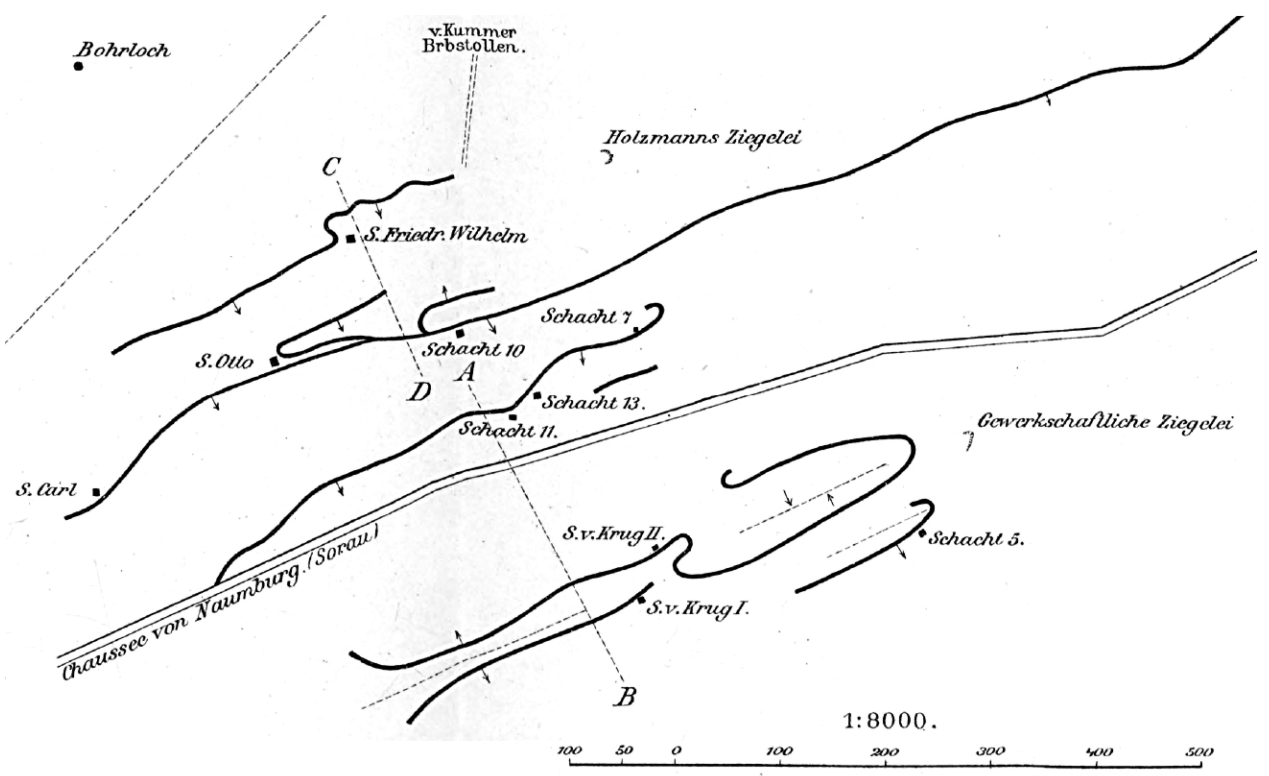

Rys. 13. Fragment mapy szybów wydobywczych oraz pokładów węgla w okolicy przysiółka Rybno, stan na r. 1891 (Rosenberg-Lipinsky, 1893, wkładka). Objaśnienia: Bohrloch - odwiert badawczy, Ziegelei - cegielnia, Schacht - szyb, Chaussee von Naumburg (Sorau) - droga z Nowogrodu (Żar) obecna ul. Łużycka. 


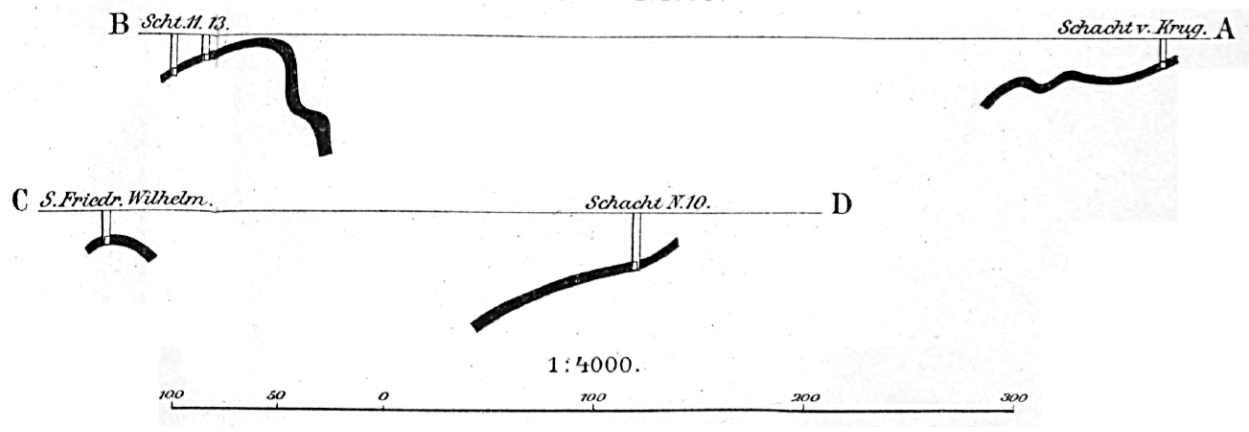

Rys. 14. Schematyczne przekroje przez pokłady węgla oraz szyby w okolicy przysiółka Rybno (Rosenberg-Lipinsky, 1893). Objaśnienia: Schacht - szyb.

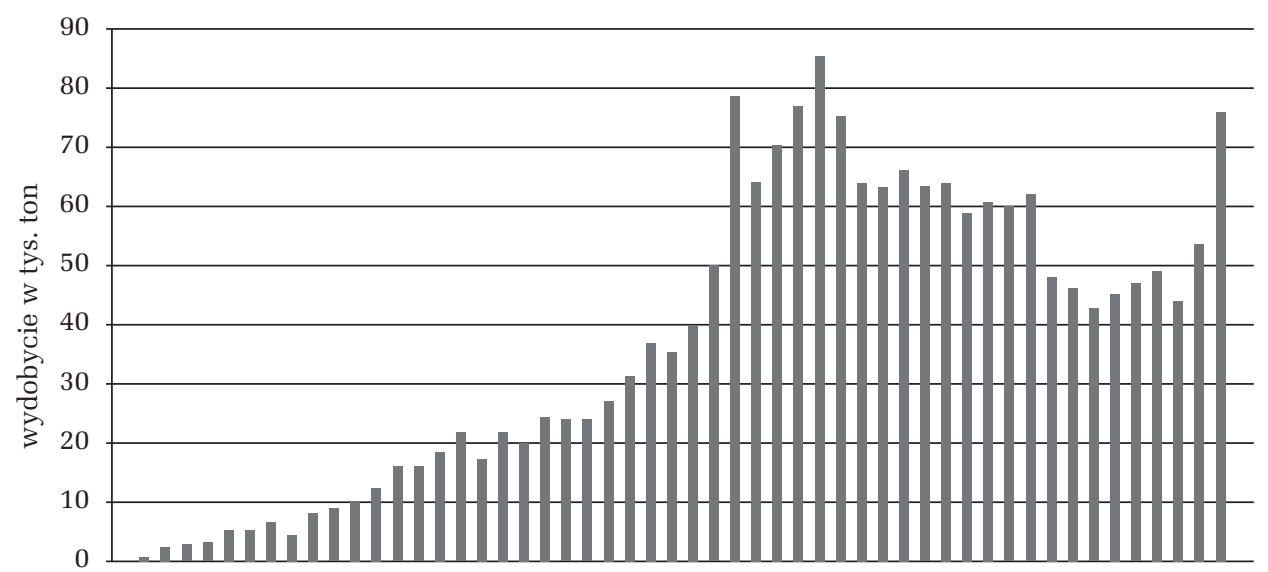

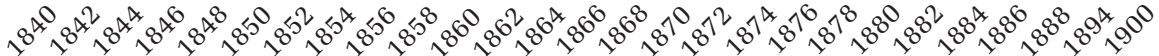

Rys. 15. Wydobycie węgla brunatnego w XIX w. przez Consolidierte Grünberger Gruben, zestawienie Autorki.
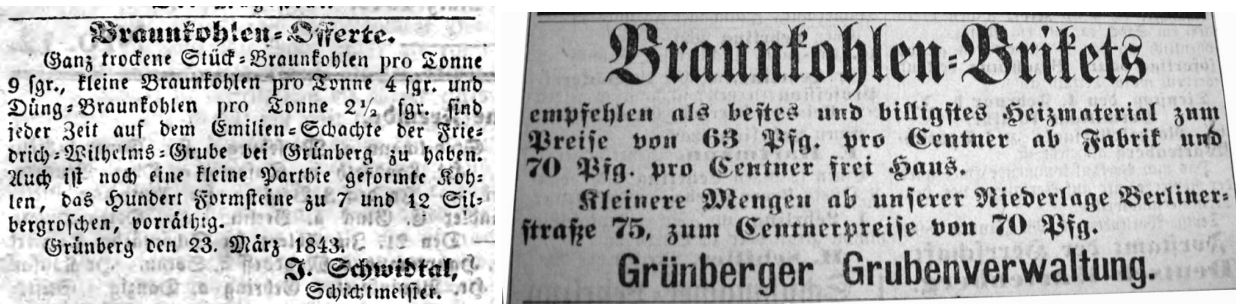

Rys. 16. Ogłoszenia o sprzedaży różnych rodzajów węgla brunatnego oraz brykietów. „Grünberger Wochenblatt" z 24 marca 1843, s. 6, oraz 2 lutego 1895, s.12. 
W 1863 r. wydrążono kolejny szyb na terenie obecnego przysiółka Rybno - szyb „Friedrich Wilhelm" o głębokości $81 / 2$ łatra (około $18 \mathrm{~m}$ ), położony na północny wschód os szybu „Emilie” (Rys. 9.), co pozwoliło na wznowienie wydobycia na tym terenie. „Consolidierte Grünberger Gruben" były wówczas drugą największą kopalnią w rejencji legnickiej $^{80}$.

W kolejnych latach (1860-1890) na terenie obecnego przysiółka Rybno oraz na południe od niego powstały szyby: 5, 7, 11, 12, 13, „Otto”, „Fuchs” (Rys. 9.), a na północ od kolonii Heinrichau (pola górnicze „Elisabeth” oraz „Victoria”) szyby „Kaiser Wilhelm I”, "Kaiser Wilhelm II", „Treutler”, „Mannigel”, „Schwarze” oraz „Haspel” (Rys. 11., Rys. 12., Tab. 2.). Od lat siedemdziesiątych XIX w. szyby $(14,17,18,19,23)$ funkcjonowały także w okolicy obecnych ulic Prostej, Leśnej oraz Wojska Polskiego. Dość dokładny opis tych szybów zamieścił w swoim artykule Rosenberg-Lipinsky81. W 1891 r. czynne były według niego cztery szyby: „Krug von Nidda I"82, „Krug von Nidda II”, 17 oraz „Kaiser Wilhelm II” (rys. 12, rys. 13). Szyby „Krug von Nidda”, 17, „Kaiser Wilhelm I" oraz „Kaiser Wilhelm II” podaje także księga pamiątkowa wydana na 50-lecie kopalni (1890 r.), dodając czynne jeszcze szyby „Helene” w Świdnicy oraz „Treutler" w Wilkanowie ${ }^{83}$.

Wydobycie węgla w tych latach ograniczało się w zasadzie wyłącznie do południowo-zachodnich okolic Zielonej Góry. Pozostałe kopalnie („Langersehnt-Glück” w Kisielinie, „Juliane” na wschód od Zielonej Góry, "Mathilde” w Raculce, „Förster" w Raculi, „Johann Carl” w Drzonkowie, "Glück Auf" w Ochli) zakończyły działalność w połowie XIX w. (dokładnych danych brak). Jedynie kopalnia „Zukunft” w Świdnicy (szyb „Helene”, Tab. 2.) przetrwała do lat dziewięćdziesiątych XIX w. ${ }^{84}$. Pod koniec w. XIX używano już wyłącznie nazwy „Consolidirte Grunberger Gruben”, wskutek wspomnianego już skonsolidowania w $1861 \mathrm{r}$.

Ilość węgla brunatnego wydobywanego przez gwarectwo „Consolidirte Grunberger Gruben" przedstawia rys. 15. Eksploatacja zwiększała się w latach 1840-1870, a następnie wynosiła około 100 tys. ton rocznie aż do wybuchu II wojny światowej. Wydobycie węgla brunatnego było uzależnione od możliwości jego zbytu, czyli głównie kondycji zielonogórskiego przemysłu. Miarą sprzedawanego węgla był początkowo buszel (niem. Scheffel) oraz tona pruska (4 buszle), a następnie hektolitr (100 litrów) oraz cetnar (niem. Zentner, 51,45 kg) - Rys. 16.

Tona węgla w początkowych latach wydobycia kosztowała 8 srebrnych groszy (niem. Silbergroschen), w 1853 r. podrożała do 10 groszy ${ }^{85}$. Były to dość niskie ceny, porównywalne z dniówkami robotników (rębacz 1 klasy zarabiał 8 srebrnych groszy za 10-godzinny dzień pracy).

Der Bergwerkbetrieb in dem Preussischen Staate im Jahre 1863, „Zeitschrift für das Berg-Hütten u. SalinenWesen" 1864, s. 110; Der Bergwerkbetrieb in dem Preussischen Staate im Jahre 1865, „Zeitschrift für das BergHütten u. Salinen-Wesen" 1866, s. 196.

81 Rosenberg-Lipinsky, op. cit., s. 206-210.

82 Stoi to w sprzeczności z innymi źródłami i oznaczałoby, że szyb ten funkcjonował ponad 30 lat, zatem jest raczej błędną informacją.

83 Gedenkblatt, s. 28.

84 G. Berg, Die Braunkohlenlagerstätten Schlesiens, [w:] A. Jentzsch, G. Berg, Die Geologie der Braunkohlenablagerungen im östlichen Deutschland, „Abhandlungen der Königlich Preussischen Geologischen Landesanstalt. Neue Folge" 1913, z. 72, s. 103.

85 H. Peugler, Die alten fünf Bergwünsche. 100 Jahre Grünberger Braunkohlengruben, Grünberg 1940, s. 7. 
Przez pierwsze lata działalności gwarectwo „Consolidirte Grunberger Gruben” nie odnosiło większych sukcesów finansowych, o czym może świadczyć choćby osoba samego odkrywcy węgla brunatnego. Carl Adolph Pohlenz zmarł w 1866 r., właściwie prawie bez środków do życia. Jego głównym zajęciem był handel artykułami żelaznymi, ale zarówno to, jak i udziały w zielonogórskich kopalniach nie uczyniły go człowiekiem bogatym ${ }^{86}$.

Zielonogórskie złoża węgla brunatnego cechują się bardzo dużą zmiennością przestrzenną oraz skomplikowanymi warunkami geologicznymi (zaburzenia glacitektoniczne), co powodowało konieczność budowy wielu szybów wydobywczych w dość niewielkich odległościach - niekiedy nawet kilkuset metrów. Drążenie szybów jest najbardziej kosztownym elementem wydobycia kopalin. W okolicy Zielonej Góry w XIX w. powstało ponad 30 takich szybów, przy czym jednocześnie w eksploatacji były $2-3^{87}$. Powodowało to wysoki koszt wydobycia węgla. Innym problemem gwarectwa był brak fachowej siły roboczej, odczuwany szczególnie dotkliwie podczas wojen - np. podczas wojny niemiecko-francuskiej w latach 1870-1871. Gwarectwo próbowało ściągać fachowców z innych krajów - w latach siedemdziesiątych XIX w. sprowadzono 29 górników ze Szwecji, jednak po krótkim czasie wszyscy zdecydowali się na powrót do ojczyzny ${ }^{88}$.

Gwarectwo borykało się jednak przede wszystkim z koniecznością zapewnienia sobie odpowiednio dużego rynku zbytu. Po rozpoczęciu wydobycia węgla brunatnego trzeba było przekonać do jego używania przede wszystkim właścicieli zakładów przemysłowych. W połowie XIX w. głównym materiałem opałowym było drewno oraz węgiel kamienny, był on jednak trudno dostępny w Zielonej Górze i drogi ze względu na koszty transportu (pochodził głównie z Anglii i był sprowadzany drogą morską oraz Odrą). Węgiel śląski stał się dostępny dopiero po doprowadzeniu do miasta kolei (1871 r.), jednak nadal był drogim surowcem. W Zielonej Górze (liczącej niecałe 10 tys. mieszkańców) w 1840 r. działała w przemyśle tylko jedna maszyna parowa (opalana drewnem) - w fabryce Jeremiasa Förstera ${ }^{89}$. Pozostałe maszyny fabryczne napędzane były siłą płynącej wody.

Przykładem zachęty do używania węgla brunatnego może być artykuł zamieszczony w „Grünberger Wochenblatt" w 1841 r., przedstawiający jego szerokie zalety ${ }^{90}$. Kopalnia oddała nawet do użytku specjalny piec dostosowany do opalania węglem brunatnym. Pierwszą fabryką, w której zastosowano węgiel brunatny jako paliwo do maszyny parowej była przędzalnia Röstel, Augspach \& Comp., a drugą tkalnia Förstera, współwłaściciela gwarectwa ${ }^{91}$. W latach siedemdziesiątych XIX w. węgiel brunatny stał się najważniejszym materiałem opałowym w Zielonej Górze i okolicach, a z fabryk wyparł go dopiero prąd elektryczny ${ }^{92}$.

Zachęcano także zwykłych mieszkańców do używania węgla brunatnego. W listopadzie 1843 r. kopalnia zaoferowała darmową przeróbkę domowych pieców przystosowa-

86 Ibid., s. 8.

87 G. Berg, op. cit., s. 98.

88 H. Peugler, op. cit., s. 8.

89 Gedenkblatt, s.11.

90 „Grünberger Wochenblatt” 1841, nr 48, s. 1.

91 Gedenkblatt, s.11.

92 W. Krajniak, op. cit., s. 124. 
nych do spalania drewna, tak aby można było je opalać węglem brunatnym. Wymagało to 12 cegieł, 1 buszla gliny oraz około 3 godzin pracy ${ }^{93}$. Ukazywały się także artykuły na temat konstrukcji takich pieców czy też wykorzystania węgla jako nawozu w rolnictwie ${ }^{94}$.

W 1884 r. wybudowano fabrykę brykietów na zachód od Zielonej Góry, tuż przy linii kolejowej Zielona Góra - Nowogród Bobrzański (obecnie aleja Wojska Polskiego 142) ${ }^{95}$. Fabrykę połączono koleją wąskotorową z szybami w okolicy Wilkanowa (Rys. 11.). Brykiety znalazły zastosowanie jako materiał opałowy głównie w gospodarstwach domowych, a także jako surowiec do silników parowych, w hutach szkła, cegielniach oraz jako surowiec do emaliowania wyrobów żelaznych. Brykietowanie węgla brunatnego pozwoliło na zagospodarowanie jego pylastej odmiany, bardzo niepraktycznej w użyciu. Budowa fabryki nadwerężyła jednak finanse przedsiębiorstwa i spowodowało to kilkuletnią przerwę w wydobyciu węgla, zostało ono wznowione dopiero w r. $1894^{96}$.

XX w. nie przyniósł wielkich zmian w położeniu ekonomicznym kopalni. Przedsiębiorstwo musiało mierzyć się z nowym konkurentem - prądem elektrycznym, zmieniło także właściciela. Końcową datą w historii zielonogórskiej kopalni jest 1948 r., kiedy to ostatecznie zaprzestano wydobycia, a majątek kopalni został przejęty przez Zjednoczenie Przemysłu Węgla Brunatnego w Żarach ${ }^{97}$.

\section{Zakończenie}

"Consolidirte Grunberger Gruben", czyli Zjednoczone Kopalnie Zielonogórskie należą do największych oraz najdłużej działających kopalń węgla brunatnego na Ziemi Lubuskiej. Miały one znaczący wpływ na rozwój zielonogórskiego przemysłu, w szczególności w drugiej połowie XIX w. Pozwoliły na wprowadzenie do użytku maszyn parowych, co poskutkowało szybkim rozwojem tkalni i przędzalni - najważniejszych składowych zielonogórskiego przemysłu. Tutejsze kopalnie stały się przykładem dla innych ośrodków przemysłowych - np. nieodległego Gubina, gdzie poszukiwania węgla rozpoczął jeden z miejscowych fabrykantów ${ }^{98}$. Węgiel brunatny był ważnym składnikiem gospodarki także w XX w., gdyż wiele kotłów (w tym elektrowni) w Zielonej Górze było dostosowanych wyłącznie do jego spalania99. Pomimo to, "Consolidirte Grunberger Gruben" nigdy nie odniosły znaczących sukcesów ekonomicznych i przez cały okres swej działalności walczyły z różnymi przeciwnościami, zarówno gospodarczymi, jak i geologicznymi.

Wydobycie węgla po II wojnie światowej trwało bardzo krótko, mimo dość dużego zapotrzebowania na węgiel. Było to spowodowane przede wszystkim brakiem fachowców, zarówno górników dołowych, jak i kadry odpowiadającej za odwierty i poszukiwania kolejnych złóż. Złoża eksploatowane przez przejęte w 1945 r. szyby zostały wyczerpa-

\footnotetext{
93 „Grünberger Wochenblatt” 1843, nr 70, s. 1.

94 „Grünberger Wochenblatt” 1844, nr 100, s. 397-399.

95 H. Peugler, op. cit., s. 9.

96 Ibid., s. 10.

97 AP ZG, Kopalnia "Słone”, zespół 89/1973/0 Komitet Powiatowy Polskiej Partii Robotniczej w Zielonej Górze, sygn. 106.

98 M. Hempe, Kette und Schuss: die Tuchmacherei in Guben, Köln 2006, s. 86.

99 A. Patla, Gorący rok. Wspomnienia inżyniera górnika z Ziem Zachodnich 1945-1946, Katowice 1967, s. 175.
} 
ne, a dalszego rozpoznania nie podjęto. Zapewne kopalnie zielonogórskie mogły jeszcze funkcjonować i przynosić zyski przez co najmniej kilkanaście lat, podobnie jak kopalnie w okolicy Żar, Smogór czy Łęknicy.

Ze względu na prawie całkowity brak zachowanych materialnych śladów po zielonogórskich kopalniach materiały archiwalne: nadania, mapy górnicze, sprawozdania czy księgi hipoteczne są głównym źródłem informacji o nieistniejącym już górnictwie węgla brunatnego na tym terenie.

Niniejsza praca, opierająca się na zachowanych archiwaliach oraz XIX-wiecznej literaturze próbuje odtworzyć pierwsze lata działalności „Consolidirte Grunberger Gruben". Należy jednak pamiętać, że w przyszłości mogą pojawić się nowe materiały, które pozwolą na jeszcze dokładniejsze jej opisanie.

\section{Bibliografia}

Banduch R., Mapy górnicze ze zbiorów Wyższego Urzędu Górniczego we Wrocławiu w latach 1769-1945, „Prace Naukowe Instytutu Górnictwa Politechniki Wrocławskiej” 2006, nr 117.

Berg G., Die Braunkohlenlagerstätten Schlesiens, [w:] Die Geologie der Braunkohlenablagerungen im östlichen Deutschland, red. A. Jentzsch, G. Berg, „Abhandlungen der Königlich Preussischen Geologischen Landesanstalt. Neue Folge" 1913, z. 72.

Bujkiewicz Z., Kopalnia węgla brunatnego w Zielonej Górze, "Studia Zielonogórskie” 1997, nr 3.

Cramer H., Beiträge zur Geschichte des Bergbaues in der Provinz Brandenburg, Heft 1, Kreis Sternberg, Halle 1872.

Czajka W., Der Schlesische Landrücken, Eine Landeskunde Nordschlesiens, Teil II, Breslau 1938.

Die Protokolle des Preußischen Staatsministeriums 1817-1934/38. Band 4/2, Hildesheim 2003.

Freydank H., Otto Krug von Nidda, [w:] Neue Deutsche Biographie, t. 13, 1982, s. 116-117.

Gedenkblatt zum 50jährigen Bestehen der Consolidirten Grünberger Gruben, Grünberg in Schl. 1890.

Gontaszewska A.: Eksploatacja węgla brunatnego w regionie lubuskim, [w:] Wydobycie węgla brunatnego i rekultywacja terenów pokopalnianych $w$ regionie lubuskim, red. A. Greinert, Instytut Inżynierii Środowiska Uniwersytetu Zielonogórskiego, Zielona Góra 2015.

Gontaszewska-Piekarz A., W poszukiwaniu najstarszej kopalni węgla brunatnego na Ziemi Lubuskiej, „Przegląd Geologiczny” t. 65, 2017, nr 9.

Gontaszewska-Piekarz A., „Caroline \& Herrmann” - pierwsza kopalnia węgla brunatnego na tle górnictwa Ziemi Lubuskiej, "Studia Zachodnie” 2018, nr 19.

Gontaszewska A., Kraiński A., „Consolidierte Grünberger Gruben” - zarys historii, [w:] Dzieje górnictwa - element europejskiego dziedzictwa kultury 3, red. P. Zagożdżon, M. Madziarz, Wrocław 2010. 
Göppert H., Ueber das Braunkohlenlager bei Laasan, „Berg- und hüttenmännische Zeitung" 1843.

Hempe M., Kette und Schuss: die Tuchmacherei in Guben, Köln 2006.

Hertel G., Die ältesten Lehnbücher der Magdeburgischen Erzbischöfe, Halle 1883.

Jaros J., Słownik historyczny kopalń węgla na ziemiach polskich, Katowice 1984.

Knie J.G., Alphabetisch-statistisch-topographisch Uebersicht der Dörfer, Flecken, Städte und andern Orte der Königl. Preuß. Provinz Schlesien, Breslau 1845.

Krajniak W., Elektryfikacja Ziemi Lubuskiej 1894-1955, „Studia Zachodnie” 2015, nr 17.

Patla A., Gorący rok. Wspomnienia inżyniera górnika z Ziem Zachodnich 1945-1946, Katowice 1967,.

Peugler H., Die alten fünf Bergwünsche. 100 Jahre Grünberger Braunkohlengruben, Grünberg 1940.

Plettner E., Die Braunkohle In der Mark Brandenburg Ihre Verbreitung und Lagerung, Berlin 1852.

Pohlenz C.A., Kurze Nachricht, die Entdeckung der Braunkohlenlager in der Umgegend von Grünberg betreffend, [w:] „Abhandlungen der Naturforschenden Gesellschaft zu Görlitz" t. 5, 1848, z. 1.

Rosenberg-Lipinsky, Die Verbereitung der Braunkohlen-formation im nördlichen Theile der Provinz Schlesien, „Jahrbuch der Königlich Preussischen Geologischen Landesamt und Bergakademie zu Berlin für das Jahr 1891" t. 12, 1893.

Staszewski R., Wypiór R., Rozwój górnictwa na Ziemiach Zachodnich Polski, [w:] Z geologii Ziem Zachodnich, t. 1, Wrocław 1966.

Stein E., Die Stadt Grünberg i. Schlesien, Berlin-Friedenau 1928.

Weimann, Ueber den Braunkohlenbau bei Grünberg, [w:] Uebersicht der Arbeiten und Veränderungen der schlesischen Gesellschaft für vaterländische Kultur, Breslau 1842.

Zimmermann A. H., Ostpreussens Bernstein und Lausitzer Braunkohle, „Sächsisches Archivblatt" 2005, nr 2.

Zincken C.F., Die Physiographie der Braunkohle, Leipzig 1867.

Żaba J., Historia eksploatacji surowców mineralnych, [w:] Surowce mineralne Ziemi Lubuskiej, red. S. Kozłowski, Warszawa 1978.

Żaba J., Historia eksploatacji węgla brunatnego na terenie Środkowego Nadodrza, „Prace Naukowe Uniwersytetu Śląskiego” 1977, nr 169, Seria Geologia, nr 1.

\section{Czasopisma}

„Amts-Blatt Königlichen Regierung Liegnitz" 1854, nr 53.

Der Bergwerkbetrieb in dem Preussischen Staate im Jahre 1852, „Zeitschrift für das Berg-, Hütten u. Salinen-Wesen" 1854.

Der Bergwerkbetrieb in dem Preussischen Staate im Jahre 1854, „Zeitschrift für das Berg-, Hütten- und Salinenwesen im Preussischen Staate" 1856.

Der Bergwerkbetrieb in dem Preussischen Staate im Jahre 1855, „Zeitschrift für das Berg-, Hütten u. Salinen-Wesen" 1856.

Der Bergwerkbetrieb in dem Preussischen Staate im Jahre 1857, „Zeitschrift für das Berg-, Hütten u. Salinen-Wesen" 1858. 
Der Bergwerkbetrieb in dem Preussischen Staate im Jahre 1863, "Zeitschrift für das Berg-, Hütten u. Salinen-Wesen" 1864.

Der Bergwerkbetrieb in dem Preussischen Staate im Jahre 1865, „Zeitschrift für das Berg-, Hütten u. Salinen-Wesen" 1866.

„Der Berkwerksfreund - ein Zeitblatt für Berg- und Hüttenleute", t. 6, 1843.

„Grünberger Wochenblatt" 1843, nr 12.

"Grünberger Wochenblatt" 1849, nr 64.

"Grünberger Wochenblatt" 1843, nr 5.

„Grünberger Wochenblatt"1843, nr 70.

„Grünberger Wochenblatt" 1844, nr 100.

"Grünberger Wochenblatt" 1895, nr 9.

„Wochenschrift des Schlesischen Vereins für Berg- und Hüttenwesen” 1860, nr 45.

"Wochenschrift des Schlesischen Vereins für Berg- und Hüttenwesen" 1861, nr 2.

„Wochenschrift des Schlesischen Vereins für Berg- und Hüttenwesen" 1861, nr 13.

„Wochenschrift des Schlesischen Vereins für Berg- und Hüttenwesen" 1861, nr 21.

„Zeitschrift für das Berg-, Hütten u. Salinen-Wesen” 1864

\section{Materiały archiwalne}

Archiwum Państwowe w Zielonej Górze

Zespół 89/45/0 Sąd Obwodowy w Zielonej Górze

sygn. 4158 Acta betr. das Hypotheken Wesen der Braunkohlen Zeche Glückauf zu Mittel Ochelhermsdorf, vol. I.

sygn. 4159 Acta betr. das Hypotheken Wesen der Braunkohlen Zeche Consolidirte Carl zu Laetnitz, Gewerkschaft Emma-Braunkohlgrube, vol. I.

sygn. 4157 Grundakten Grunberg, Braukohlengrube Juliane, Bd II BI. 37, Gewerkschaft Emma-Braunkohlgrube.

Zespół 89/1973/0 Komitet Powiatowy Polskiej Partii Robotniczej w Zielonej Górze sygn. 106 Kopalnia "Słone”.

\section{Sächsisches Staatsarchiv Freiberg}

Zespół 40048 (preußisches) Bergamt (Bergrevier) Görlitz.

Nr. 1-698: Repräsentanten und Grubenvorstände - Allgemein, Auflösung der Gewerkschaften Amsel, Gottessegen und Glückauf in Grünberg.

Nr. 1-468: Braunkohlenbergwerk Konsolidierte Grünberger Gruben bei Grünberg - Berechtigung.

Archiwum Państwowego Instytutu Geologicznego we Warszawie, nieskatalogowane zbiory prof. E. Ciuka (kopie map)

Situation und Profile über die Bohr und Schurfarbeit auf Wittgenauer und Schloiner Terrain. Kgl. Oberbergamt Breslau, 1840.

Karte von der Umgebung von Grünberg, 1844.

Mapa pól górniczych gwarectwa „Consolidirte Grünberger Gruben” na terenie obecnego przysiółka Rybno, ok. 1905.

Kolekcja kuksów Marka Koneckiego 
Zaświadczenie nr 29 o posiadaniu dwóch kuksów gwarectwa „Consolidirte Grünberger Gruben".

\section{Mapy}

Deutsche Karte, arkusz 346, 1893.

G.D. Reymann's topographische Special-Karte von Central Europa, arkusz 112 Glogau, 1831.

Mapa górnicza kopalni „Consolidierte Grünberger Gruben”, arkusz B20, 1917.

AGNIESZKA GONTASZEWSKA-PIEKARZ - geolog, adiunkt w Instytucie Budownictwa Uniwersytetu Zielonogórskiego. Naukowo zajmuje się warunkami geologicznoinżynierskimi Ziemi Lubuskiej, a także historią górnictwa węgla brunatnego na tym terenie. Autorka dwóch monografii oraz ponad 50 publikacji naukowych. E-mail: a.gontaszewska@ib.uz.zgora.pl 